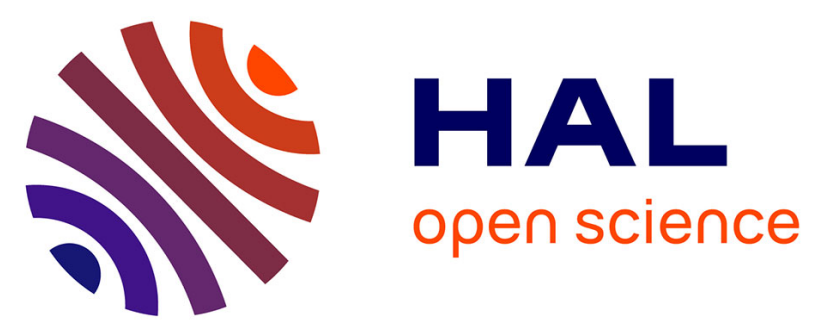

\title{
Chiral Side Groups Trigger Second Harmonic Generation Activity in 3D Octupolar Bipyrimidine-Based Organic Liquid Crystals
}

Stijn Van Cleuvenbergen, Przemyslaw Kędziora, Jean-Luc Fillaut, Thierry

Verbiest, Koen Clays, Huriye Akdas-Kilig, Franck Camerel

\section{To cite this version:}

Stijn Van Cleuvenbergen, Przemyslaw Kędziora, Jean-Luc Fillaut, Thierry Verbiest, Koen Clays, et al.. Chiral Side Groups Trigger Second Harmonic Generation Activity in 3D Octupolar BipyrimidineBased Organic Liquid Crystals. Angewandte Chemie International Edition, 2017, 56 (32), pp.95469550. 10.1002/anie.201705138. hal-01578551

HAL Id: hal-01578551

https://hal-univ-rennes1.archives-ouvertes.fr/hal-01578551

Submitted on 6 Oct 2017

HAL is a multi-disciplinary open access archive for the deposit and dissemination of scientific research documents, whether they are published or not. The documents may come from teaching and research institutions in France or abroad, or from public or private research centers.
L'archive ouverte pluridisciplinaire HAL, est destinée au dépôt et à la diffusion de documents scientifiques de niveau recherche, publiés ou non, émanant des établissements d'enseignement et de recherche français ou étrangers, des laboratoires publics ou privés. 


\section{Chiral Side Groups Trigger Second Harmonic Generation Activity in 3D Octupolar Bipyrimidine-based Organic Liquid Crystals}

By Stijn van Cleuvenbergen,* Przemysław Kędziora, Jean-Luc Fillaut, Thierry Verbiest, Koen Clays, Huriye Akdas-Kilig,* and Franck Camerel*

Dr. Huriye Akdas-Kilig, Dr. Jean-Luc Fillaut, Dr. Franck Camerel

Institut des Sciences Chimiques de Rennes, UMR 6226 CNRS-Université de Rennes 1, Campus de Beaulieu, 35042 Rennes, France.

Email: huriye.akdas@univ-rennes1.fr; fcamerel@univ-rennes1.fr

Dr. Przemysław Kędziora

Polish Academy of Sciences, Institute of Molecular Physics, Smoluchowskiego 17, 60-179 Poznań, Poland.

Dr. Stijn van Cleuvenbergen, Dr. Thierry Verbiest, Dr. Koen Clays

Department of Chemistry, Katholieke Universiteit Leuven, Celestijnenlaan 200D and F, B3001 Leuven, Belgium.

Email: stijn.vancleuvenbergen@kuleuven.be

\section{Abstract.}

Design of organic noncentrosymmetric materials remains the Holy Grail in the field of second-order nonlinear optics. Unlike inorganic crystals currently used in second-order nonlinear optical applications, organic materials represent an attractive alternative due to their 
fast electro-optical response and processability, but their alignment into noncentrosymmetric film still remains challenging. Here, symmetry breaking by judicious functionalization of 3D organic octupoles allows the emergence of multifunctional liquid crystalline chromophores which can easily be processed into large, flexible, thin and self-oriented films presenting second harmonic generation responses competitive to the prototypical inorganic $\mathrm{KH}_{2} \mathrm{PO}_{4}$ crystals. Additionally, liquid crystalline nature of these chiral organic films permits the modulation of the nonlinear optical properties due to the sensitivity of the supramolecular organization to temperature leading to the development of tunable macroscopic material.

Keywords: Bipyrimidine, Liquid Crystals, Thin Films, Nonlinear Optic, Chirality

Noncentrosymmetric (NCS) compounds are of current interest in materials chemistry because of their technologically important second-order nonlinear optical properties, with applications such as second harmonic generation (SHG), electro-optical switching, telecommunications, optical computing, laser technologies and bioimaging. ${ }^{[1]}$ The development of numerous nonlinear optical (NLO) inorganic crystals, such as $\mathrm{BaB}_{2} \mathrm{O}_{4}(\mathrm{BBO}),{ }^{[2]} \mathrm{LiB}_{3} \mathrm{O}_{5}$ (LBO), ${ }^{[3]}$ $\mathrm{KH}_{2} \mathrm{PO}_{4}(\mathrm{KDP}),{ }^{[4]} \mathrm{KTiOPO}_{4}(\mathrm{KTP}),{ }^{[5]} \mathrm{AgGaS}_{2}(\mathrm{AGS}){ }^{[6]}$ and $\mathrm{AgGaGeS}_{4}$ (AGGS), ${ }^{[7]}$ has led to significant advances in the application of laser devices from UV to IR spectral wavelengths. NCS crystals of organic molecules such as nitroaniline derivatives are efficient for second order applications as well. ${ }^{[8]}$ However, crystalline materials lack processability and growing large high-quality crystals remains challenging. Alternatively, NLO activity can be achieved in polymeric films by using the "poling process", in which a strong electric field is applied to align dipolar organic chromophores inside a polymer matrix near its glass transition temperature $\left(\mathrm{T}_{\mathrm{g}}\right)$. Unfortunately, after cooling, the obtained NLO-active polymeric materials lack long-term stability and reproducibility of the preparation process, while the strong 
electric fields used during the poling process can lead to degradation. The Langmuir-Blodgett film deposition technique has also been used to create NCS films using amphiphilic chromophores but the tedious monolayer-by-monolayer deposition method remains a main obstacle. ${ }^{[10]}$

Liquid crystalline materials open another route for creating functional organic NLO materials. They offer numerous advantages such as their ease of processing into high-quality thin films, their self-healing capacity and the possibility of alignment by shear forces, surface treatment or electric or magnetic fields. ${ }^{[11]}$ The formation of NCS liquid crystals containing optically active cores is a promising way to achieve efficient organic thin films for SHG.

Engineering organic liquid crystalline materials for second-order nonlinear optical applications is challenging, since at least 3 requirements must be met: i) a large molecular NLO response (i.e. first hyperpolarizability $\beta$ ), requiring NCS on the molecular level, ii) liquid crystalline behavior and iii) a supramolecular NCS organization. Since this approach relies on supramolecular self-assembly for creating NCS materials, octupolar chromophores can be incorporated as well. Octupolar compounds offer important advantages over dipolar molecules such as reduced polarization sensitivity and better transparency-efficiency tradeoff, ${ }^{[12]}$ but cannot be aligned by electric field poling. We have recently demonstrated that the grafting of long (achiral) carbon chains on the 3 and 4 positions of 3D octupolar styryl bipyrimidine (BPM) cores of $\mathrm{D}_{2}$ symmetry allows for the emergence of liquid crystals displaying strong third-order NLO activity (two-photon fluorescence). While these compounds showed a second-order NLO response on the molecular level, the formation of centrosymmetric columnar $(\mathrm{Col})$ mesophases of hexagonal symmetry did not allow the emergence of an SHG response. ${ }^{[13]}$ An elegant way to break centrosymmetry is the introduction of chirality. Since chiral materials lack inversion symmetry, the bulk NCS order is guaranteed by an efficient chirality transfer from the molecular to the supramolecular 
level. ${ }^{[14]}$ De Vega et al. grafted chiral chains on planar (2D) $C_{3}$ symmetric ester endcapped alkynylbenzenes derivatives, ${ }^{[15]}$ which allowed formation of chiral discotic nematic liquid crystals able to act as an active layer in NLO devices. Formation of $\mathrm{Col}$ mesophases from polar discotic molecules can also lead to a spontaneous macroscopic polarization resulting in ferroelectricity associated to a strong SHG response. ${ }^{[16]}$

In the present work, we were able to tune supramolecular interactions in the mesophase of 3D octupolar BPM compounds by grafting enantiomerically pure chiral dihydrocitronellyl chains which are known to induce supramolecular chirality. This triggered a NCS organization, obtaining either right- or left-handed helical Col mesophases, as evidenced by circular dichroism (CD) spectroscopy. This way, we obtained high quality thin films displaying a strong SHG response, which was found to be comparable to that of prototypical KDP. ${ }^{[17]}$

Chiral compounds BPM-(S)-C8(2) and BPM-(R)-C8(2) were readily prepared from dialkoxybenzaldehydes carrying chiral carbon chains, R or S 3,7-dimethyloctane in the 3 and 4 positions as previously reported procedure (Scheme 1). ${ }^{[18]}$ The yellow sticky compounds were obtained in good yields $(\sim 80 \%)$ and further fully characterized by NMR, UV-vis, mass spectroscopy and elemental analysis, confirming the expected molecular structure and the symmetrical substitution pattern on the BPM. DFT calculation also confirms that the molecule has a non-planar $\mathrm{D}_{2}$ configuration (Scheme $\left.1 \mathrm{~b}\right)$. 


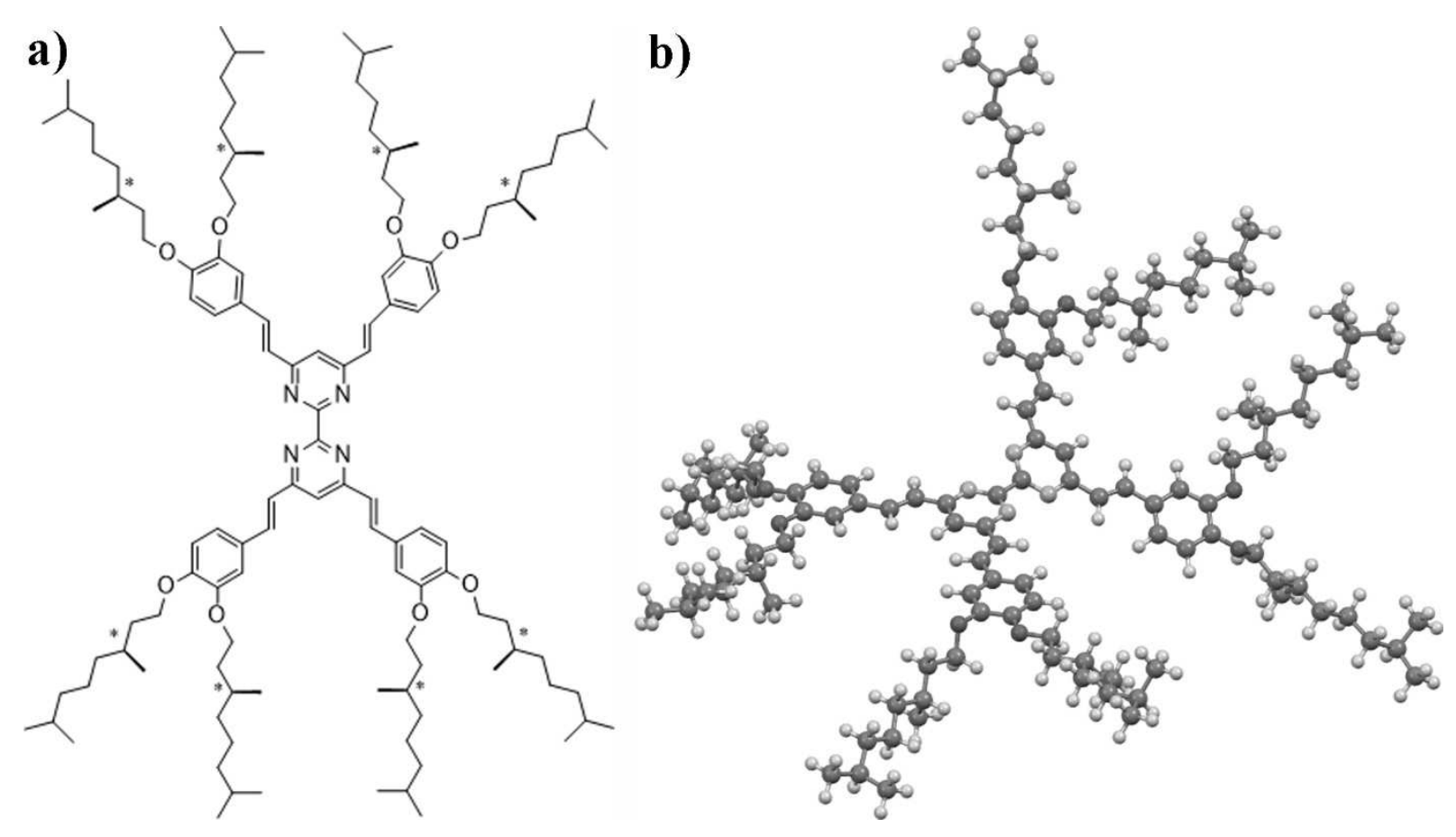

Scheme 1. a) Molecular structure of the chiral BPM compounds; b) Geometry optimized molecular structure of the BPM-(R)-C8(2) compound (B3LYP/6-31G*, central torsion angle $30.33^{\circ}$ in vacuum).

The absorption and emission properties of BPM-(S)-C8(2) and BPM-(R)-C8(2) compounds were first investigated in dichloromethane (Figure S1 and Table S1). The absorption spectra display one main absorption maximum around $380 \mathrm{~nm}$ which can be assigned to multiple $\pi-\pi^{*}$ electronic transitions implying electronic delocalization along the stilbenyl $\pi-$ linkers with a charge transfer from the alkoxy electron-donating groups to the BPM electron deficient core. Excitation at $380 \mathrm{~nm}$ leads to a strong emission at $485 \mathrm{~nm}$ with quantum yields around $25 \%$. The compounds are also strongly luminescent in the solid state, even at high temperature (Figure S2), displaying a broad emission band centered at $500 \mathrm{~nm}$ (Figure S3). The emission in the solid state is slightly redshifted $(\Delta \lambda \sim 15 \mathrm{~nm})$ relative to that in solution. Note that the linear optical properties in solution and in solid state of analogous compounds bearing achiral side chains, described earlier, yield similar results. ${ }^{[13]}$ 
The first hyperpolarizability of the 3D octupolar compounds was determined by hyperRayleigh scattering (HRS). ${ }^{[19]}$ As for the achiral analogues described in earlier work, these chromophores give rise to multiphoton fluorescence at this wavelength. A fluorescence-free $\beta$-value was obtained through the high frequency demodulation technique, ${ }^{[7-8]}$ and a fluorescence lifetime could be derived as well. The $\beta$ values of the SHG active chiral octupoles are given in Table 1. They are within error identical for both compounds, and for the compounds reported previously as well, meaning that the conjugated system governing the second-order NLO response is not influenced by the difference in side chain length (as for the emission properties). This clearly demonstrate the quadratic NLO activity of these novel chiral octupolar chromophores in solution.

Table1. Hyperpolarisability and lifetime values in dichloromethane

\begin{tabular}{|c|c|c|c|}
\hline & $\beta_{800 \mathrm{~nm}}{ }^{\mathrm{a}} / 10^{-30} \mathrm{e}$ & $\beta_{0}^{b} / 10^{30}$ esu & $\tau_{\mathrm{f}}(\mathrm{ns})$ \\
\hline$\overline{B P M-(R)-C 8(2)}$ & $670 \pm 190$ & $48 \pm 14$ & 1.62 \\
\hline BPM-(S)-C8(2) & $700 \pm 160$ & $66 \pm 15$ & 1.23 \\
\hline \multicolumn{2}{|c|}{ BPM-3,4-C12 ${ }^{[13]} 500 \pm 80$} & \multicolumn{2}{|l|}{$38 \pm 8$} \\
\hline \multicolumn{2}{|c|}{ BPM-3,4-C16 ${ }^{[13]} 485 \pm 25$} & $42 \pm 7$ & \\
\hline
\end{tabular}

Differential Scanning Calorimetry (DSC) traces of the two compounds display a reversible transition centered at $88^{\circ} \mathrm{C}$ and at $96^{\circ} \mathrm{C}$ for BPM-(R)-C8(2) and BPM-(S)-C8(2) respectively (Figure S4). POM observations showed an isotropic state above these temperatures. On cooling from the isotropic melt, pseudo-fan-shaped textures, characteristic of Col mesophases, rapidly develop (Figure 1a). A glass transition is also observed around $40{ }^{\circ} \mathrm{C}$. Polarized Optical Microscopy (POM) observations showed that below $\mathrm{Tg}$, the material was a brittle and 
birefringent solid and that, above $\mathrm{Tg}$, the material was soft, viscous and malleable but still birefringent (Figure S5). The observed glass transition may indicate a slow crystallization of the material at low temperature and the preservation of the pseudo-fan-shaped texture indicates that the Col organization is preserved below Tg. These results suggest that the two chiral compounds appear to be in a liquid crystalline state from the glass transition observed around $40{ }^{\circ} \mathrm{C}$ up to the isotropization temperature around $100^{\circ} \mathrm{C}$. The various phase transitions were also confirmed by POM measurements (Figure S6). For both compounds, the transmitted light rapidly increases at the isotropic to mesophase transition, in line with the formation of a birefringent texture. A plateau is reached within the mesomorphic temperature range down to the glass transition around $40{ }^{\circ} \mathrm{C}$, upon which a slight increase of the transmitted light is observed. These observations confirm the presence of a mesophase between $40{ }^{\circ} \mathrm{C}$ and $100{ }^{\circ} \mathrm{C}$, in line with the DSC curves and POM images.

The two compounds provide small angle X-ray scattering (SAXS) patterns unambiguously characteristic of a well-organized hexagonal $\mathrm{Col}$ mesophase $\left(\mathrm{Col}_{\mathrm{h}}\right)$ between $40{ }^{\circ} \mathrm{C}$ and $100{ }^{\circ} \mathrm{C}$ (Figure $1 \mathrm{~b}$ and Figure S7). In the low-angle region three sharp maxima are detected, the reciprocal spacing of which are in the ratio $1: \sqrt{3}: 2$, reflecting the formation of a 2D hexagonal lattice with constant $a=26 \AA$ at $80^{\circ} \mathrm{C}$. In addition, the diffuse halo at about 4.7 $\AA$ is characteristic of the conformationally-disordered branched alkyl chains. The molecular packing inside the mesophase cannot be properly described in view of the limited information that can be extracted from the SAXS pattern. However, the organization is probably close to the one proposed for the parent molecules with linear carbon chains for which the 3D octupoles are interdigitated alternatively along their long axis and their short axis to form columns. ${ }^{[13]}$ In the present case, due to the presence of chiral lateral chains, a helical twist of the columns can be envisaged to explain the formation of the CD active nanostructure (vide infra). ${ }^{[20]}$ In the glassy state, below $40{ }^{\circ} \mathrm{C}$, only a shoulder starts to grow around $3.0^{\circ}$ on the 
edge of the fundamental peak and the third-order reflections (20) gradually disappear (Figure S7), in line with a slight 2D lattice distortion preserving the Col arrangements in the glassy state. The mean distance between the chains slightly decreases upon cooling. In the isotropic liquid, only a broad halo is observed in the small angle region together with the one in the wide angle region, reflecting the mean distances between the BPM cores and the chains, respectively.
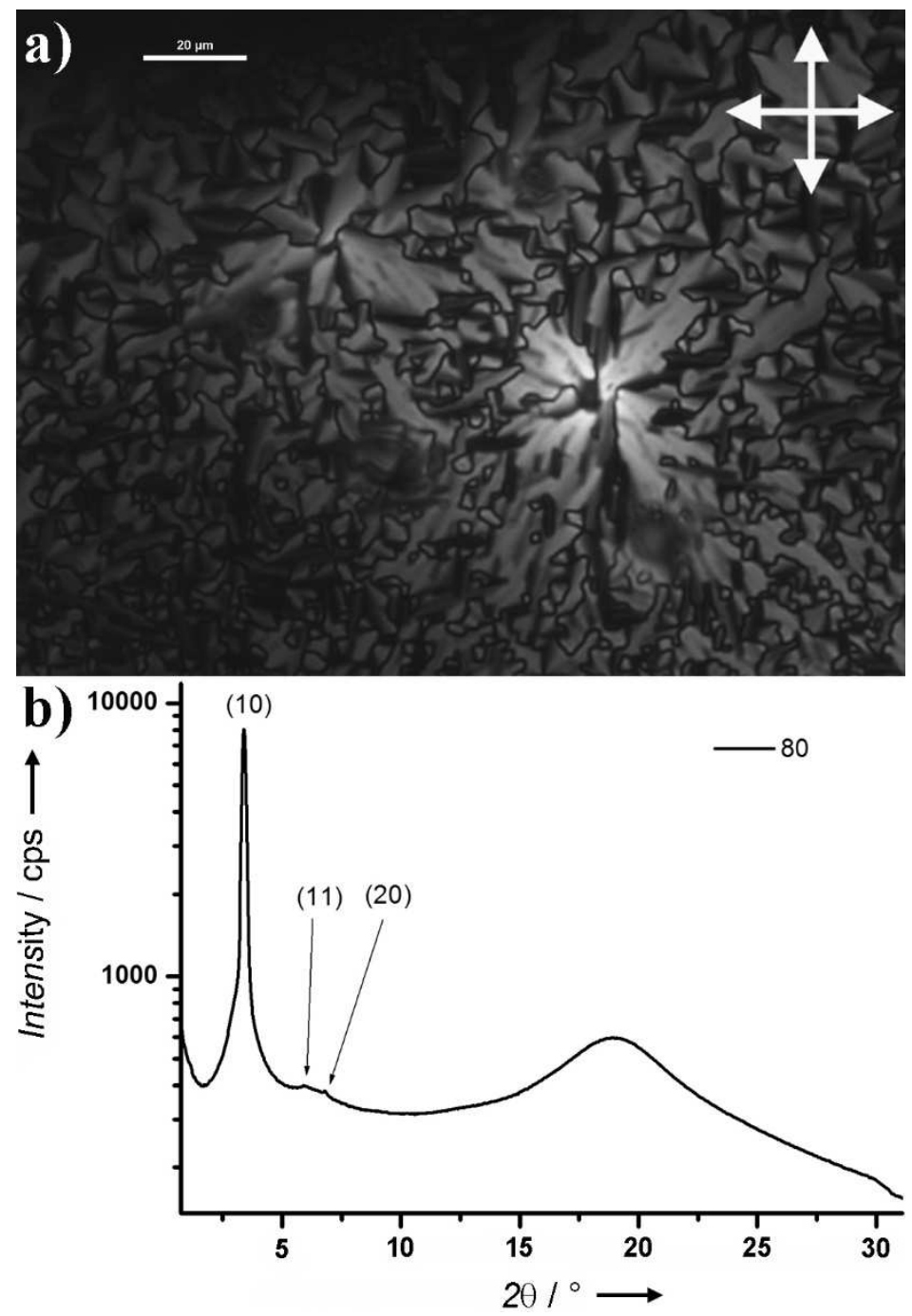

Figure 1. a) BPM-(R)-C8(2) compound observed by POM at $91{ }^{\circ} \mathrm{C}$ after slow cooling from the isotropic melt; b) SAXS patterns of BPM-(R)-C8(2) compound in the hexagonal Col mesophase at $80{ }^{\circ} \mathrm{C}$ after heating at $120^{\circ} \mathrm{C}$. 
The solid-state CD spectra of the two enantiomeric compounds, recorded at room temperature after heating at $120{ }^{\circ} \mathrm{C}$, show $\mathrm{CD}$ bands in the visible region (Cotton effect) with opposite sign, in line with the formation of helices of opposite handedness (Figure 2). Due to strong absorption the CD signal becomes undetectable below $410 \mathrm{~nm}$ and only the onset of the Cotton band could be measured. We accounted for possible artefacts due to sample anisotropy ${ }^{[21]}$ by rotating the sample around its azimuth as in earlier work. ${ }^{[1 c]}$ Note that solutions of the compounds in chloroform were found to be CD-inactive in the recorded wavelength region, showing that the simple connection of the chiral chains is not sufficient to import chiro-optical effects on the BPM core. It is therefore the supramolecular organization inside the condensed phase that generates the $\mathrm{CD}$ band, demonstrating the efficient transfer of the chirality from the stereogenic fragment to the center of the columns which creates a NCS packing around the BPM core. ${ }^{[22]}$
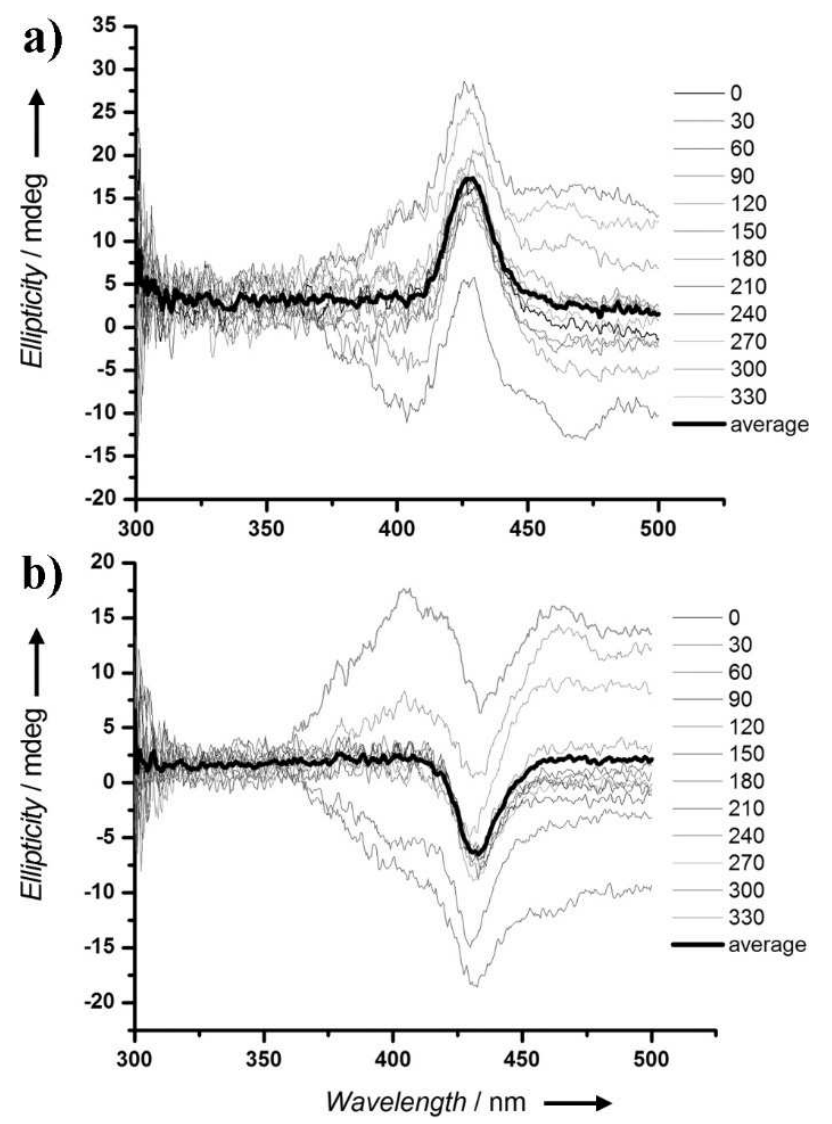
Figure 2. Individual spectra for different azimuthal rotation angles (in degrees) and rotationally averaged CD spectra for (a) BPM-(R)-C8(2) compound and (b) BPM-(S)-C8(2) compounds show opposite Cotton effect (after rotational averaging the true CD effect appears).

To determine their application potential in NLO devices, good quality thin films with homogenous large surface area were measured by spectral SHG at $1000 \mathrm{~nm}$ (Figure 3). For the glassy state of both enantiomers at room temperature, a strong SHG peak rises above a broad (multiphoton) fluorescence background. We subsequently subjected the samples to heating/cooling cycles while continuously measuring the SHG response. The thermotropic behavior of these compounds is expected to have a marked effect on the signal strength, as SHG is very sensitive to supramolecular organization and will vanish in case of centrosymmetric order. Upon heating, the SHG signal remains present over the entire mesophase for both compounds although it decreases to some extent. This can be attributed to a loss of order due to increasing mobility at higher temperatures, i.e. the response is controlled by the temperature-dependent degree of noncentrosymmetry in the mesophase.. Note that the SHG signal is stable when the temperature is kept constant. Once the isotropic phase is reached the signal vanishes as expected for this centrosymmetric phase. Upon cooling a clear transition is found upon entering the mesophase for both compounds, while the transition to the glassy state is clear for the BPM-(R)-C8(2) compound but somewhat less marked for the BPM-(S)-C8(2) analogue. Since i) the achiral analogues described in earlier work did not show any SHG activity, ${ }^{[12]}$ and ii) chiral sidegroups induce supramolecular chirality for the films studied here as evidenced by CD spectroscopy, we can attribute the strong SHG signal in these films to a NCS supramolecular chiral organization. 


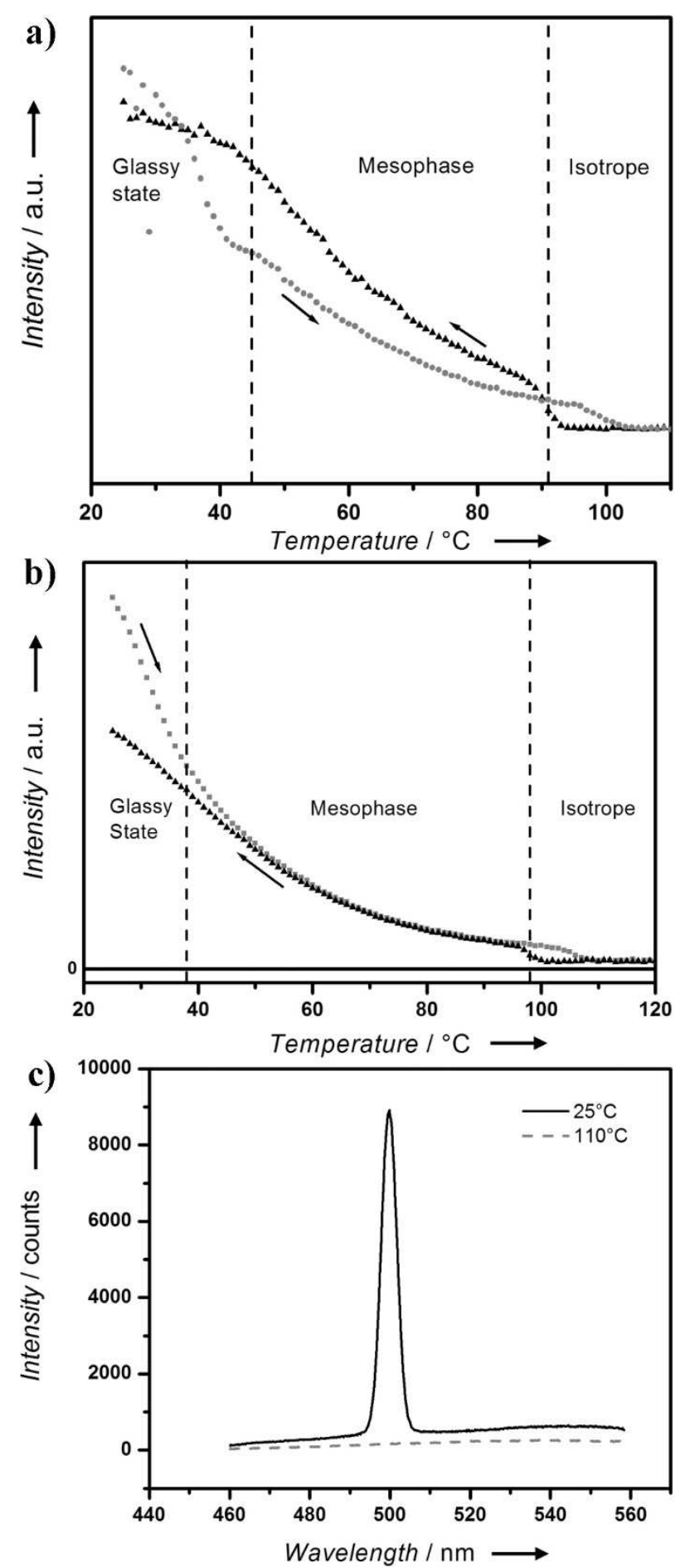

Figure 3. SHG signal strength as a function of temperature for heating and cooling $\left(5^{\circ} \mathrm{C} / \mathrm{min}\right)$ of BPM-(R)-C8(2) (a) and BPM-(S)-C8(2) (b) compound; c) Typical SHG spectra for compound BPM-(S)-C8(2) at $25^{\circ} \mathrm{C}$ and $110^{\circ} \mathrm{C}$. In the isotropic phase, the SHG vanishes while a multiphoton fluorescence contribution remains evident 
To quantify the NLO response, we measured the SHG signal of the BPM-(R)-C8(2) compound against a $\mathrm{BBO}$ reference material at room temperature. An average second-order nonlinear optical coefficient of $0.19 \pm 0.03 \mathrm{pm} / \mathrm{V}$ was found at room temperature, which is of the order of currently used inorganic materials such as $\mathrm{KDP}^{[17]}$ This value at room temperature can be related to different temperatures by comparing with the temperature dependent SHG measurements, and for the BPM-(R)-C8(2) compound the value for $\left\langle\mathrm{d}_{\mathrm{eff}}>\right.$ varies from about $0.06 \mathrm{pm} / \mathrm{V}$ to $0.15 \mathrm{pm} / \mathrm{V}$ at the high and low temperature edges of the mesophase respectively (Fig. S9).

In conclusion, the grafting of ramified chiral alkyl chains on 3D octupolar BPM cores has allowed the emergence of NCS crystalline and liquid crystalline phases. CD and SAXS measurements have revealed that these $3 \mathrm{D}$ octupolar $\left(\mathrm{D}_{2}\right)$ chromophores are organized into right or left handed twisted Col supramolecular aggregates depending on the chirality of the side chains. The compounds are easily processed into self-oriented large area flexible thin films. In contrast to structurally analogous compounds with achiral sidechains which we explored in earlier work, ${ }^{[13]}$ this strategy allows translation of the nonlinear optical response from the molecular level (determined by HRS measurements) to the bulk level (determined by SHG measurements). Along side strong fluorescence and two-photon absorption properties in the solid state, these materials display a marked SHG response under $1000 \mathrm{~nm}$ laser irradiation, on the order of inorganic crystals such as KDP. The SHG response can moreover be tuned by temperature in the crystalline and the liquid crystalline phase and switches off completely in the isotropic phase. This simple rational design_strategy, i.e. grafting of chiral fragments, allows the NCS organization of various 2D and 3D octupoles into soft, malleable and processable materials and has great potential for the development of flexible and large area materials for second-order NLO applications. Moreover, these materials, can be 
combined with photochromic fragments, Light Induced Excited Spin State Trapping (LIESST) materials or photo-responsive single molecular magnets which are appealing for the development of thin films for 3D storage of information.

\section{References}

[1] a) W. R. Zipfel, R. M. Williams, W. W. Webb, Nat. Biotechnol. 2003, 21, 1369; b) F. Helmchen, W. Denk, Nat. Meth. 2005, 2, 932; c) S. Van Cleuvenbergen, G. Hennrich, P. Willot, G. Koeckelberghs, K. Clays, T. Verbiest, M. A. van der Veen, J. Phys. Chem. C 2012, 116, 12219; d) M. Lee, H. E. Katz, C. Erben, D. M. Gill, P. Gopalan, J. D. Heber, D. J. McGee, Science 2002, 298, 1401; e) Y. Shi, C. Zhang, H. Zhang, J. H. Bechtel, L. R. Dalton, B. H. Robinson, W. H. Steier, Science 2000, 288, 119.

[2] C. Chen, B. Wu, A. Jiang, G. You, Sci. Bin. 1985, 28, 235.

[3] C. Chen, A. Jiang, B. Wu, G. You, R. Li, S. Lin, J. Opt. Soc. Am. B 1989, 6, 616.

[4] M. A. Rhodes, B. Woods, J. J. DeYoreo, D. Roberts, L. J. Atherton, App. Opt. 1995, 34,5312 .

[5] a) K. Kato, IEEE J. Quant. Electron. 1991, 27, 1137; b) M. E. Hagerman, K. R. Poeppelmeier, Chem. Mater. 1995, 7, 602.

[6] a) D. S. Chemla, P. J. Kupecek, D. S. Robertson, R. C. Smith, Opt. Commun. 1971, 3, 29-31; b) G. C. Bhar, R. C. Smith, Phys. Status Solidi A 1972, 13, 157; c) G. Boyd, H. Kasper, J. McFee, IEEE J. Quant. Electron. 1971, 7, 563.

[7] V. Petrov, V. Badikov, G. Shevyrdyaeva, V. Panyutin, V. Chizhikov, Opt. Mater. 2004, 26, 217.

[8] H. Nalwa, S. Miyata, Boca Raton, FL 1996, 397.

[9] a) D. S. Chemla, J. Zyss, Nonlinear Optical Properties of Organic Molecules and Crystals, Academic Orlando, FL, 1987; b) Z. Zekkat, W. Knoll, Photoreactive Organic Thin Films, Academic Press, Elsevier, 2002.

[10] T. L. Penner, H. R. Motschmann, N. J. Armstrong, M. C. Ezenyilimba, D. J. Williams, Nature 1994, 367, 49.

[11] a) K. G. Gutierrez-Cuevas, L. Wang, Z. G. Zheng, H. K. Bisoyi, G. Li, L. S. Tan, R. A. Vaia, Q. Li, Angew. Chem. Int. Ed. 2016, 55, 13090; Angew. Chem. 2016,128, 13284-13288; b) L. Wang, Q. Li, Adv. Funct. Mater. 2016, 26, 10.

[12] K. Senechal, O. Maury, H. Le Bozec, I. Ledoux, J. Zyss, J. Am. Chem. Soc. 2002, 124, 4560 .

[13] H. Akdas-Kilig, M. Godfroy, J.-L. Fillaut, B. Donnio, B. Heinrich, P. Kędziora, J.-P. Malval, A. Spangenberg, S. van Cleuvenbergen, K. Clays, F. Camerel, J. Phys. Chem. C 2015, 119, 3697.

[14] a) T. Wöhrle, I. Wurzbach, J. Kirres, A. Kostidou, N. Kapernaum, J. Litterscheidt, J. C. Haenle, P. Staffeld, A. Baro, F. Giesselmann, et al., Chem. Rev. 2016, 116, 1139; b) Y. Okada, S. Matsumoto, Y. Takanishi, K. Ishikawa, S. Nakahara, K. Kishikawa, H. Takezoe, Phys. Rev. E 2005, 72, 20701; c) D. Miyajima, F. Araoka, H. Takezoe, J. Kim, K. Kato, M. Takata, T. Aida, J. Am. Chem. Soc. 2010, 132, 8530; d) D. Miyajima, F. Araoka, H. Takezoe, J. Kim, K. Kato, M. Takata, T. Aida, Science 2012, 336, 209; e) D. Miyajima, F. Araoka, H. Takezoe,J. Kim, K. Kato, M. Takata, T. Aida, Angew. Chem. Int. Ed. 2011, 50, 7865; Angew. Chem. 2011, 123, 8011. 
[15] L. de Vega, S. van Cleuvenbergen, G. Depotter, E. M. García-Frutos, B. Gómez-Lor, A. Omenat, R. M. Tejedor, J. L. Serrano, G. Hennrich, K. Clays, J. Org. Chem. 2012, 77, 10891.

[16] a) J. Grolik, Ł. Dudek, J. Eilmes, A. Eilmes, M. Górecki, J. Frelek, B. Heinrich, B. Donnio, Tetrahedron 2012, 68, 3875; b) J. Grolik, Ł. Dudek, J. Eilmes, Tetrahedron Lett. 2012, 53, 5127; c) M. H. C. J. Van Houtem, R. Martin-Rapun, J. A. J. M.

Vekemans, E. W. Meijer, Chem. Eur. J. 2010, 16, 2258; d) E. Beltrán, E. Cavero, J. Barbera, J. L. Serrano, A. Elduque, R. Giménez, Chem. Eur. J. 2009, 15, 9017; e) J. Kirres, F. Knecht, P. Seubert, A. Baro, S. Laschat, ChemPhysChem 2016, 17, 1159.

[17] D. Eimerl, Ferroelectrics 1987, 72.

[18] H. Akdas-Kilig, T. Roisnel, I. Ledoux, H. Le Bozec, New J. Chem. 2009, 33, 1470.

[19] a) T. Verbiest, F. Meyers, J. L. Brédas, K. Clays, A. Persoons, Opt. Lett. 1993, 18, 525-527; b) K. Clays, A. Persoons, Phys. Rev. Lett. 1991, 66, 2980.

[20] a) H. Lee, D. Kim, H.-K. Lee, W. Qiu, N.-K. Oh, W.-C. Zin, K. Kim, Tetrahedron Lett. 2004, 45, 1019; b) R. Ziessel, F. Camerel, B. Donnio, Chem. Rec. 2009, 9, 1.

[21] R. Kuroda, T. Harada, Y. Shindo, Rev. Sci. Instrum. 2001, 72, 3802.

[22] S. Debnath, J.-F. Bergamini, F. Artzner, C. Meriadec, F. Camerel, M. Fourmigue, Chem. Commun. 2012, 48, 2283. 


\section{TOC}

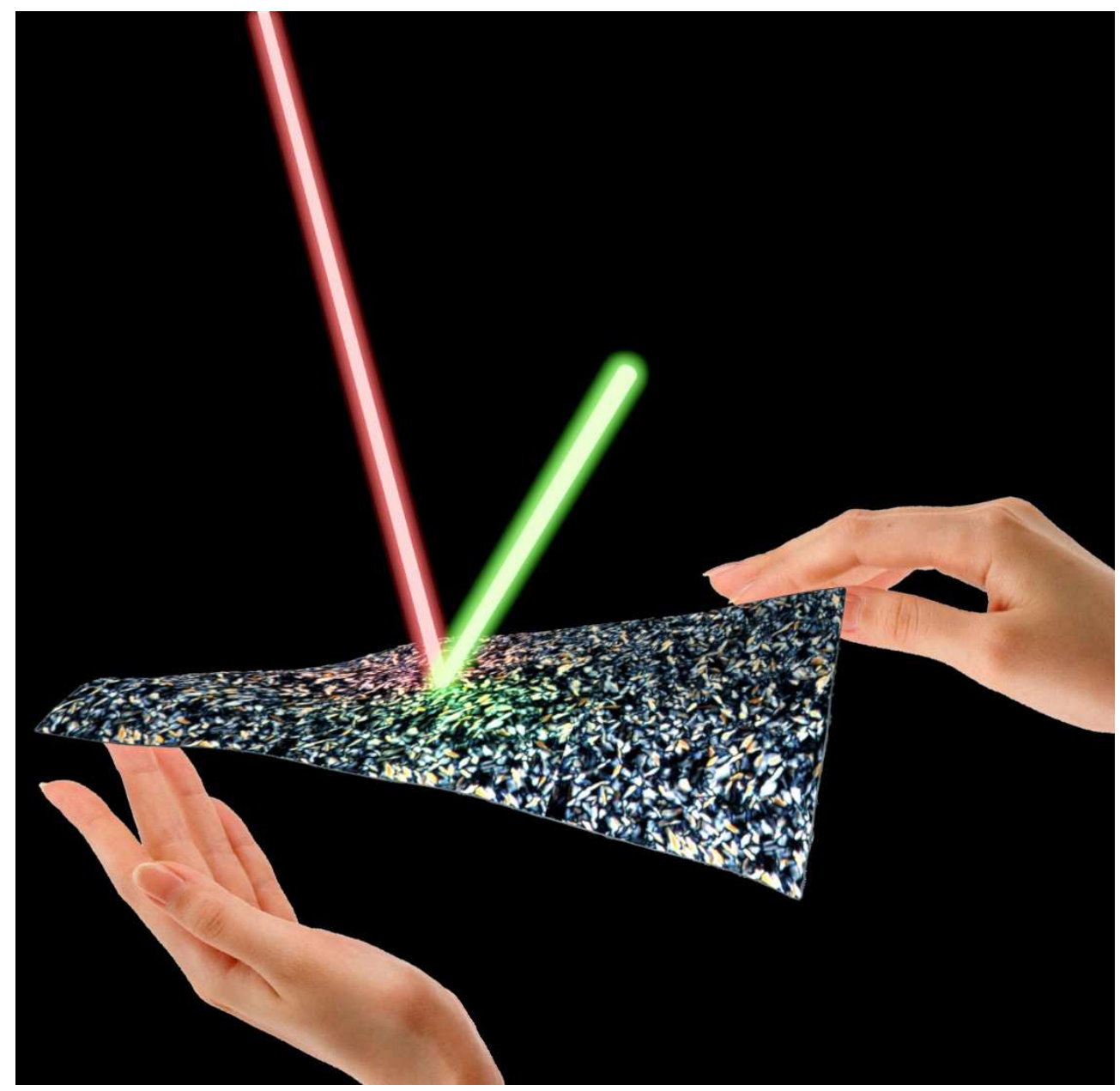

The rational design of chiral 3D octupoles allows the formation of high-quality flexible organic liquid crystalline thin film displaying strong $2^{\text {nd }}$ harmonic generation, competitive to the prototypical inorganic crystalline material $\mathrm{KH}_{2} \mathrm{PO}_{4}(\mathrm{KDP})$.

Acknowledgments. F.C. thanks the GENCI for allocation of computing time under project 2017-A0020805032. The authors thank the French, Polish and Belgian Ministries of Research and Higher Education for their supports through the Hubert Curien Partnerships POLONIUM (2016-2017) and TOURNESOL (2016-2017). Jean-François Bergamini is also gratefully acknowledged for his help for the TOC design. S.V.C. is grateful for financial support from 
FWO Flanders for his postdoctoral fellowship. T.V. acknowledges support from the Hercules Foundation.

\section{Competing interests}

The authors declare no competing financial interests. 


\section{Supporting information}

\section{Methods.}

NMR spectroscopy: NMR spectra $\left({ }^{1} \mathrm{H},{ }^{13} \mathrm{C}\right)$ were recorded at room temperature on BRUKER $\operatorname{ASCEND}^{\mathrm{TM}} 400$ and DMX500 spectrometers operating at 400 and $500 \mathrm{MHz}$. High-resolution mass spectra were obtained on a Bruker Micro-TOF-Q II instrument or a ZabSpec TOF Micromass instrument at CRMPO, University of Rennes 1.

DFT calculations: Geometry optimization of BPM-(R)-C8(2) compound was performed on gas phase using Gaussian09 (Revision D.01) program package (B3LYP functional / 6-31G* basis set) on the French supercalculator Occigen. ${ }^{[1]}$ Gaussview version 5.09 to generate the figures. $^{[2]}$

Steady-state absorption and fluorescence spectra: The absorption measurements were carried out with a Carry 60 spectrometer. Steady-state fluorescence spectra were collected from a Edinburgh F900 spectrofluorometer. Emission spectra are spectrally corrected, and fluorescence quantum yields include the correction due to solvent refractive index and were determined relative to quinine bisulfate in 0.05 molar sulfuric acid $\left(\Phi_{\text {ref }}=0.52\right) .{ }^{[3]}$ The solvents employed for absorption and emission analysis were spectroscopic grade.

\section{Differential scanning calorimetry (DSC) and Small angle X-ray scattering experiments} (SAXS): DSC was carried out by using NETZSCH DSC 200 F3 instrument equipped with an intracooler. DSC traces were measured at $10{ }^{\circ} \mathrm{C} / \mathrm{min}$ down to $-30{ }^{\circ} \mathrm{C}$. Optical microscopy investigations were performed on a Nikon H600L polarising microscope equipped with a Linkam "liquid crystal pro system" hotstage. The microscope is also equipped with a UV irradiation source (Hg Lamp, $\lambda=350-400 \mathrm{~nm}$ ) and an ocean optic USB 2000+ UV-Vis-NIR spectrophotometer based on CCD detection technology. This set-up allows the recording of luminescence spectra on solids, liquids, liquid crystalline materials and gels from $-196^{\circ} \mathrm{C}$ up 
to $420^{\circ} \mathrm{C}$ between 350 and $1100 \mathrm{~nm}$. X-ray scattering experiments (SAXS) were performed using a FR591 Bruker AXS rotating anode X-ray generator operated at $40 \mathrm{kV}$ and $40 \mathrm{~mA}$ with monochromatic $\mathrm{Cu} \mathrm{K} \alpha$ radiation $(\lambda=1.541 \AA)$ and point collimation. The patterns were collected with a Mar345 image plate detector (Marresearch, Norderstedt, Germany). The samples were held in Lindemann glass capillaries (1 mm diameter). The sample temperature was controlled within $\pm 0.01^{\circ} \mathrm{C}$ and exposure times were $1 \mathrm{~h}$.

Electro-optic experiments: The investigated samples were placed in commercial measuring cells from Linkam (UK) with thicknesses of $7 \mu \mathrm{m}$ with the semitransparent electrodes of Indium-Tin Oxide (ITO) between crossed polarizers on the stage of the polarizing microscope MPI-5 from PZO, Warsaw.

CD spectroscopy measurements: CD spectroscopy measurements were performed on a JASCO J810 CD spectrophotometer. The incident beam is always normal to the sample plane, i.e., the glass surface. A sample holder has been designed that allows rotating the sample among its azimuth. It is also possible to turn the sample $180^{\circ}$, such that the front side, directed at the light source, becomes the back side, directed at the detector. To minimize the effects of scattering, the sample is positioned as close to the detector as possible. The sampled area is 2 $\mathrm{mm}$ in diameter. Thin film liquid crystal cells (3 micron, untreated glass) were used.

Nonlinear optical measurements: A high repetition $(80 \mathrm{MHz})$, broadband $(680-1300 \mathrm{~nm})$ femtosecond pulsed laser (Spectra-Physics InSight DS+), producing a p-polarized laser beam was used in all experiments. Intensity variation was accomplished by an achromatic half-wave plate and a polarizer in the s-direction located immediately after the laser system. Consequently, the polarization used for all experiments for the input beam was s-polarized. The pulse full width at half maximum (FWHM) was measured to be 128 fs (autocorrelator model 409-8 deployed with an etalon of $1560 \mathrm{fs}$ ). The SHG experiments were performed at a wavelength of $1000 \mathrm{~nm}$ in order to minimize multiphoton fluorescence that was found to be 
relatively strong at $800 \mathrm{~nm}$ and $900 \mathrm{~nm}$. The incident laser beam is focused into the sample by an achromatic lens $(60 \mathrm{~mm}$ EFL) and the power was kept constant at $75 \mathrm{~mW}$. The SHG light is collected by a 1" achromatic, aspheric condenser lens (focal length $30 \mathrm{~mm}$ ), subsequently focused onto the entrance slit of a spectrograph (Bruker 500 is $/ \mathrm{sm}$ ) and recorded on an EMCCD camera (Andor Solis model iXon Ultra 897). Appropriate filters (SCHOTT BG 39, SCHOTT KG 5) were chosen so as to eliminate any unwanted Rayleigh scattering entering the spectrograph. Additionally, a long pass filter is positioned in front of the first lens to eliminate any unwanted higher-order harmonics from the polarization optics and optics inside the laser. Recording times varied between 0.5 and $1 \mathrm{sec}$, and no electron-multiplying was used. The multi-photon induced fluorescence was corrected for by a linear fit over a small area around the SHG peak $( \pm 10 \mathrm{~nm})$, which was fitted with a Gaussian function. In all experiments a heating/cooling rate of $5^{\circ} \mathrm{C} / \mathrm{min}$ is applied by a temperature controlled Linkam stage.

The nonlinear optical coefficient $\left(\mathrm{d}_{\mathrm{eff}}\right)$ was quantified according to a procedure published earlier to evaluate the $d_{\text {eff }}$ of metal organic frameworks through SHG microscopy. ${ }^{[4]}$ To avoid phase matching effects the film thickness was kept minimal at 3.1 micron. The film was prepared between 2 untreated glass plates in a liquid crystal cell. Averaging over 5 different positions and 6 linear input light polarizations (all 30 apart) give the average nonlinear optical coefficient.

\section{Syntheses:}

(R)-(-)-Citronellol bromide and (S)-(+)-Citronellol were purchased from Aldrich and used as received. (R)-(-)-Citronellyl bromide and (S)-(+)-Citronellyl bromide were synthesized as previously reported from (R)-(-)-Citronellol bromide and (S)-(+)-Citronellol. ${ }^{[5]}$ (R)-(-)-1Bromo-3,7-dimethyloctane and (S)-(+)-1-Bromo-3,7-dimethyloctane were obtained from the 
corresponding citronellyl bromide derivative after reduction with palladium on activated charcoal and hydrogen gas. ${ }^{[6],[7]}$ The dialkoxybenzaldehydes carrying chiral carbon chains in the 3 and 4 positions were directly obtained by reacting the R or S Bromo-3,7-dimethyloctane derivative with 3,4-dihydroxobenzaldehyde in DMF in presence of $\mathrm{K}_{2} \mathrm{CO}_{3}{ }^{[8]}$

General procedure for the condensation of the aldehydes with 4,4',6,6'-tetramethyl-[2,2']bipyrimidine.

A stirred mixture of 4,4',6,6'-tetramethyl-[2,2']-bipyrimidine $(1.0 \mathrm{mmol})$ and the corresponding aldehyde $(5.0 \mathrm{mmol})$ in aqueous sodium hydroxide $(5 \mathrm{M}, 15 \mathrm{~mL})$ containing Aliquat $336(0.1 \mathrm{mmol})$ was heated under reflux for $72 \mathrm{~h}$. The mixture was allowed to cool, and the precipitate was filtered off, washed with water, and purified by recrystallization from dichloromethane/methanol mixture. The compounds were found to be soluble in chloroform, dichloromethane, acetone, diethylether and tetrahydrofuran and insoluble in water, pentane, ethanol and methanol.

BPM-(S)-C8(2) - yellow sticky solid, 75\% yield; ${ }^{1} \mathrm{H}$ NMR $\left(\mathrm{CDCl}_{3}, 400.16 \mathrm{MHz}\right): \delta$ ppm 7.95 $(\mathrm{d}, \mathrm{J}=15.9 \mathrm{~Hz}, 4 \mathrm{H}), 7.68(\mathrm{~s}, 2 \mathrm{H}), 7.32(\mathrm{~m}, 8 \mathrm{H}), 7.24(\mathrm{~m}, 4 \mathrm{H}), 7.06(\mathrm{~d}, \mathrm{~J}=8 \mathrm{~Hz}, 4 \mathrm{H}), 4.16$ $(\mathrm{sx}, \mathrm{J}=4.0 \mathrm{~Hz}, 16 \mathrm{H}), 1.98(\mathrm{~m}, 8 \mathrm{H}), 1.77(\mathrm{~m}, 16 \mathrm{H}), 1.61(\mathrm{~m}, 8 \mathrm{H}), 1.50-1.20(\mathrm{~m}, 48 \mathrm{H}), 1.05(\mathrm{t}$, $\mathrm{J}=8.0 \mathrm{~Hz}, 22 \mathrm{H}), 0.95\left(\mathrm{dd}, \mathrm{J}_{1}=7.2 \mathrm{~Hz}, \mathrm{~J}_{2}=4 \mathrm{~Hz}, 50 \mathrm{H}\right) .{ }^{13} \mathrm{C} \mathrm{NMR}\left(\mathrm{CDCl}_{3}, 100.62 \mathrm{MHz}\right): \delta$ ppm 164.1, 150.5, 149.3, 137.1, 128.8, 124.6, 121.9, 113.1, 111.6, 67.56, 67.46, 39.2, 37.35, 37.30, 36.23, 36.11, 29.9, 27.9, 24.6, 22.68, 22.58, 19.74, 19.71. m/z (Maldi-TOF) 1817.585 , ([M+H] $]^{+}, \mathrm{C}_{120} \mathrm{H}_{190} \mathrm{~N}_{4} \mathrm{O}_{8}$ requires 1817.47). Anal. Calcd for $\mathrm{C}_{120} \mathrm{H}_{190} \mathrm{~N}_{4} \mathrm{O}_{8}, \mathrm{CH}_{3} \mathrm{OH}: \mathrm{C}, 78.61$; H, 10.58; N, 3.03; O, 7.79. Found: C, 78.47; H, 10.705; N, 2.96; O, 7.65. $[\alpha]^{20}{ }_{\mathrm{D}}-4.7^{\circ}\left(1 \mathrm{~g} . \mathrm{L}^{-1}\right.$, $\left.\mathrm{CH}_{2} \mathrm{Cl}_{2}\right)$ 
BPM-(R)-C8(2) - yellow solid, 81\% yield ${ }^{1} \mathrm{H}$ NMR $\left(\mathrm{CDCl}_{3}, 400.16 \mathrm{MHz}\right): \delta \mathrm{ppm} 7.95(\mathrm{~d}, \mathrm{~J}=$ $15.9 \mathrm{~Hz}, 4 \mathrm{H}), 7.68(\mathrm{~s}, 2 \mathrm{H}), 7.32(\mathrm{~m}, 8 \mathrm{H}), 7.24(\mathrm{~m}, 4 \mathrm{H}), 7.06(\mathrm{~d}, \mathrm{~J}=8 \mathrm{~Hz}, 4 \mathrm{H}), 4.16(\mathrm{sx}, \mathrm{J}=$ $4.0 \mathrm{~Hz}, 16 \mathrm{H}), 1.98(\mathrm{~m}, 8 \mathrm{H}), 1.77(\mathrm{~m}, 16 \mathrm{H}), 1.61(\mathrm{~m}, 8 \mathrm{H}), 1.50-1.20(\mathrm{~m}, 48 \mathrm{H}), 1.05(\mathrm{t}, \mathrm{J}=8.0$ $\mathrm{Hz}, 22 \mathrm{H}), 0.95\left(\mathrm{dd}, \mathrm{J}_{1}=7.2 \mathrm{~Hz}, \mathrm{~J}_{2}=4 \mathrm{~Hz}, 50 \mathrm{H}\right) .{ }^{13} \mathrm{C} \mathrm{NMR}\left(\mathrm{CDCl}_{3}, 100.62 \mathrm{MHz}\right): \delta \mathrm{ppm}$ $164.2,164.0,150.7,149.4,137.3,129.0,124.8,122.1,113.2,111.7,67.7,67.6,39.4,37.53$, 37.49, 36.4, 36.2, 30.1, 29.9, 28.1, 24.9, 22.9, 22.8, 19.89, 19.86. m/z (Maldi-TOF) 1817.630, ([M+H] $]^{+}, \mathrm{C}_{120} \mathrm{H}_{190} \mathrm{~N}_{4} \mathrm{O}_{8}$ requires 1817.47). Anal. Calcd for $\mathrm{C}_{120} \mathrm{H}_{190} \mathrm{~N}_{4} \mathrm{O}_{8}$ : C, 79.33; H, 10.54; N, 3.08; O, 7.04. Found: C, 79.22; H, 10.51; N, 3.04; O, 7.26. $[\alpha]^{20}{ }_{\mathrm{D}}+7.2^{\circ}\left(1 \mathrm{~g} . \mathrm{L}^{-1}, \mathrm{CH}_{2} \mathrm{Cl}_{2}\right)$ 

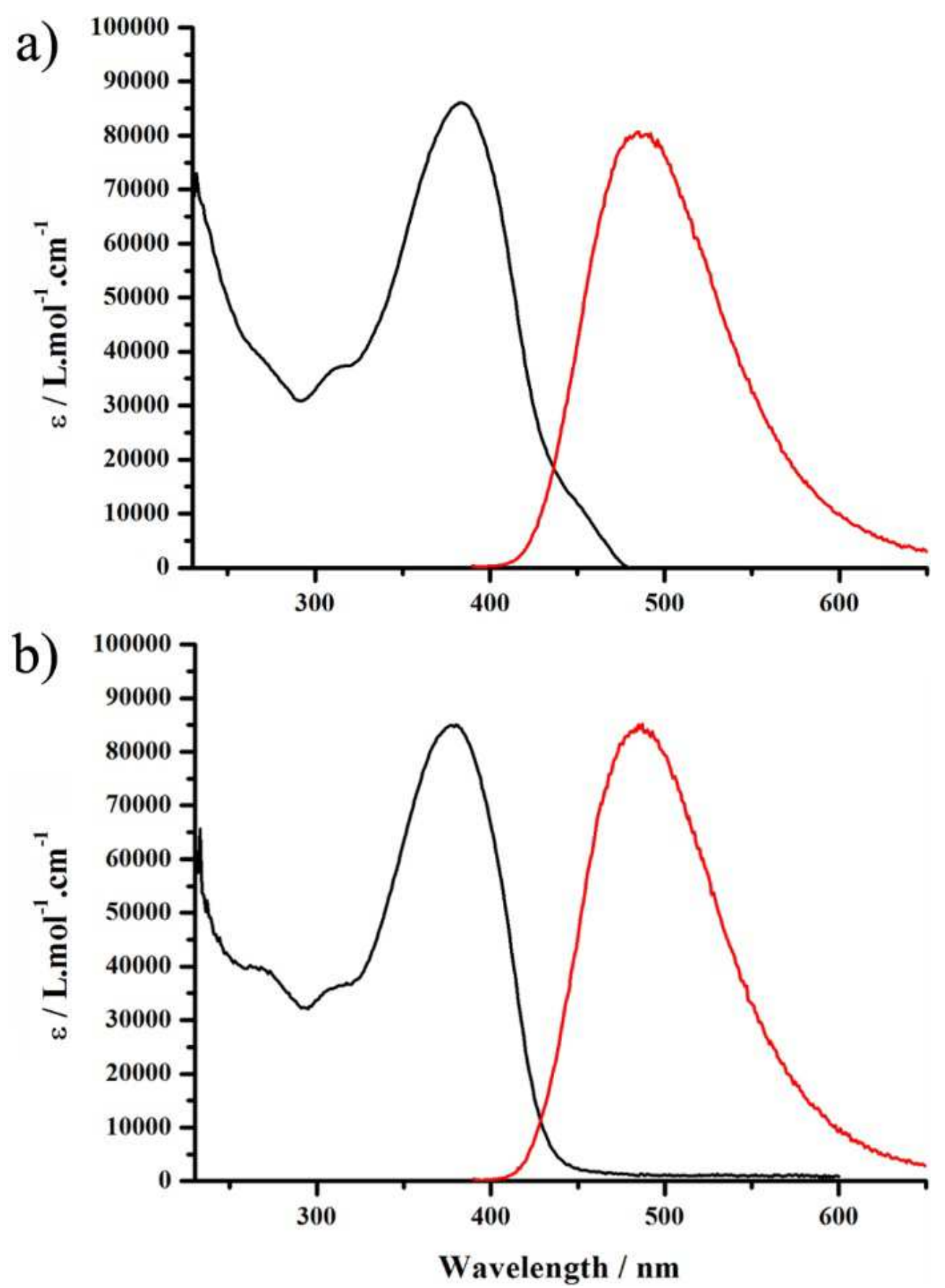

Figure S1. Absorption (black curve) and emission (red curve) spectra of (a) BPM-(R)-C8(2) $\left(\mathrm{C}=2.53 \times 10^{-6} \mathrm{M}\right)$ and $(\mathrm{b}) \mathbf{B P M}-(\mathbf{S})-\mathbf{C 8}(2)\left(\mathrm{C}=2.64 \times 10^{-6} \mathrm{M}\right)$ in dichloromethane at room temperature. 


\begin{tabular}{lcccc}
\hline & $\begin{array}{c}\varepsilon^{M A X} \\
/ \mathrm{M}^{-1} \mathrm{~cm}^{-1}\end{array}$ & $\begin{array}{c}\lambda_{\text {abs }} \max \\
/ \mathrm{nm}\end{array}$ & $\begin{array}{c}\lambda_{\text {fluo }} \\
/ \mathrm{nm}\end{array}$ & $\Phi_{\text {fluo }}$ \\
\hline BPM-(R)-C8(2) & 86100 & 383 & 485 & 0.27 \\
\cline { 2 - 5 } BPM-(S)-C8(2) & 85000 & 380 & 485 & 0.25 \\
\cline { 2 - 5 } & & & & \\
\hline
\end{tabular}

Table S1. Spectroscopic data of compounds in dichloromethane (DCM).

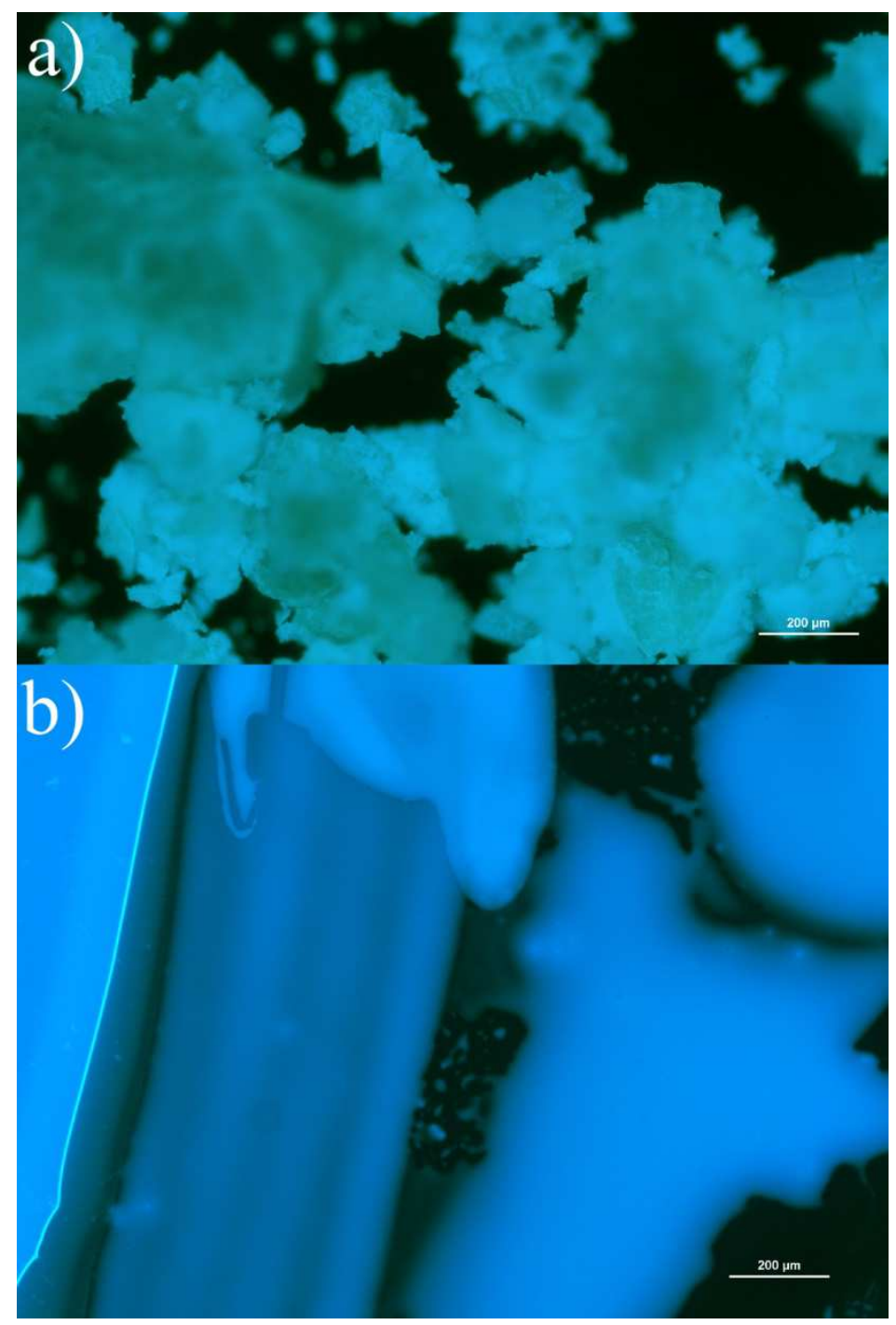

Figure S2. a) Pristine powder of BPM-(R)-C8(2) observed by optical microscopy at room temperature under UV irradiation; b) Thin film of BPM-(R)-C8(2) under UV irradiation at $122^{\circ} \mathrm{C}$ in the isotropic state $\left(340<\lambda_{\mathrm{ex}}<380 \mathrm{~nm}\right)$. 


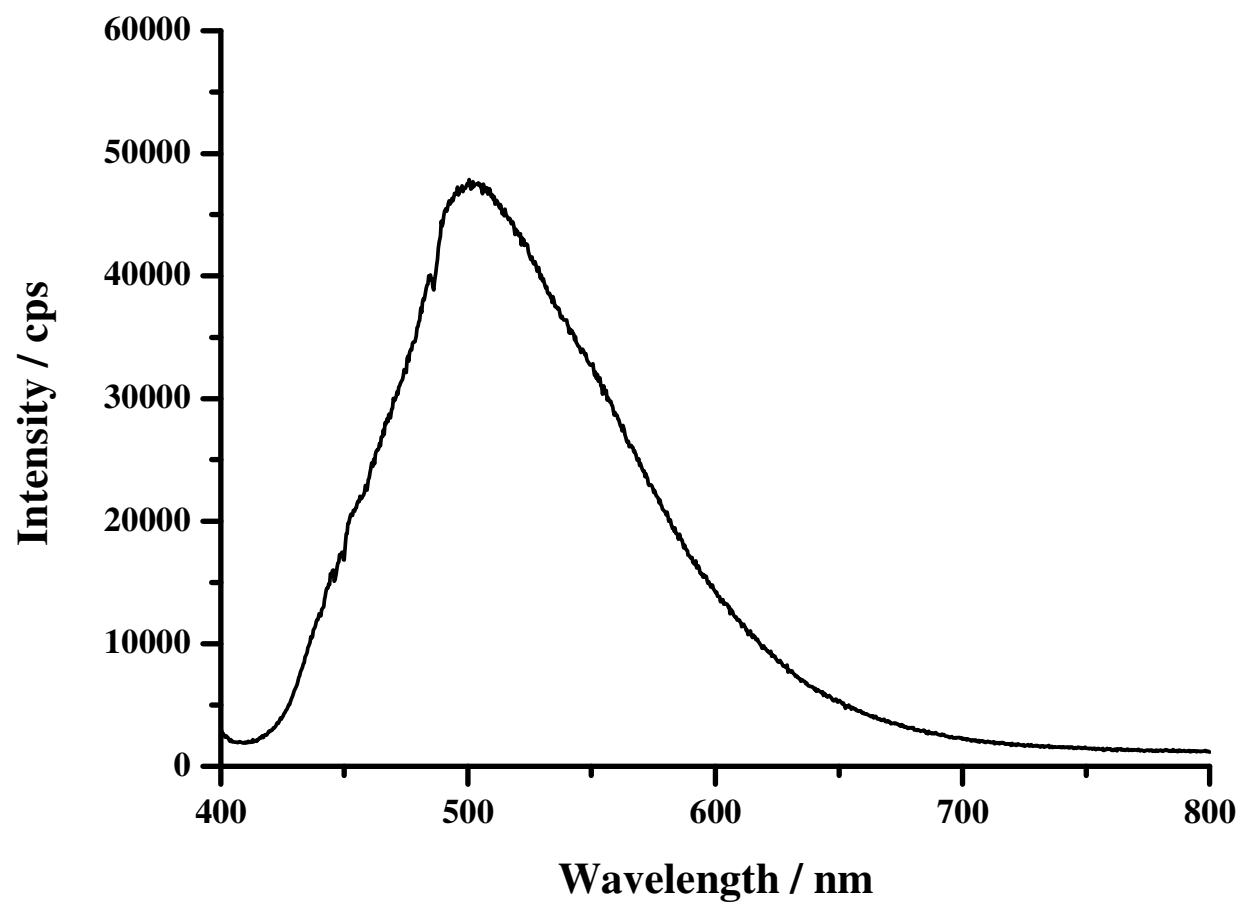

Figure S3. Solid state emission spectrum of BPM-(S)-C8(2) compound at room temperature (340 $<\lambda_{\text {ex }}<380 \mathrm{~nm}$ ). 

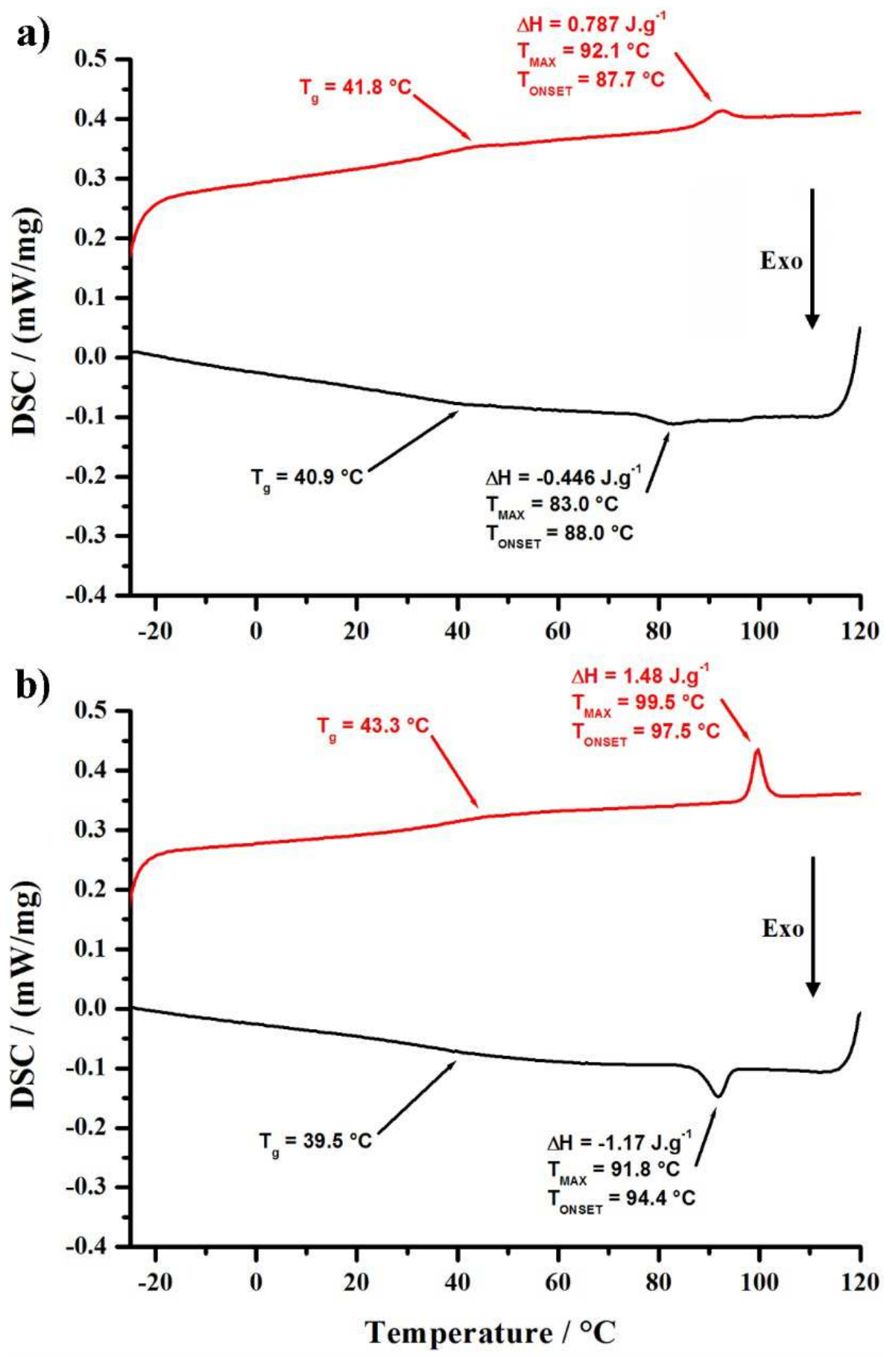

Figure S4. DSC traces of BPM-(R)-C8(2) (a) and BPM-(S)-C8(2) (b) compounds (red : 2nd heating curve; black : 1 st cooling curve; scan rate $=10^{\circ} \mathrm{C} / \mathrm{min}$ ). 

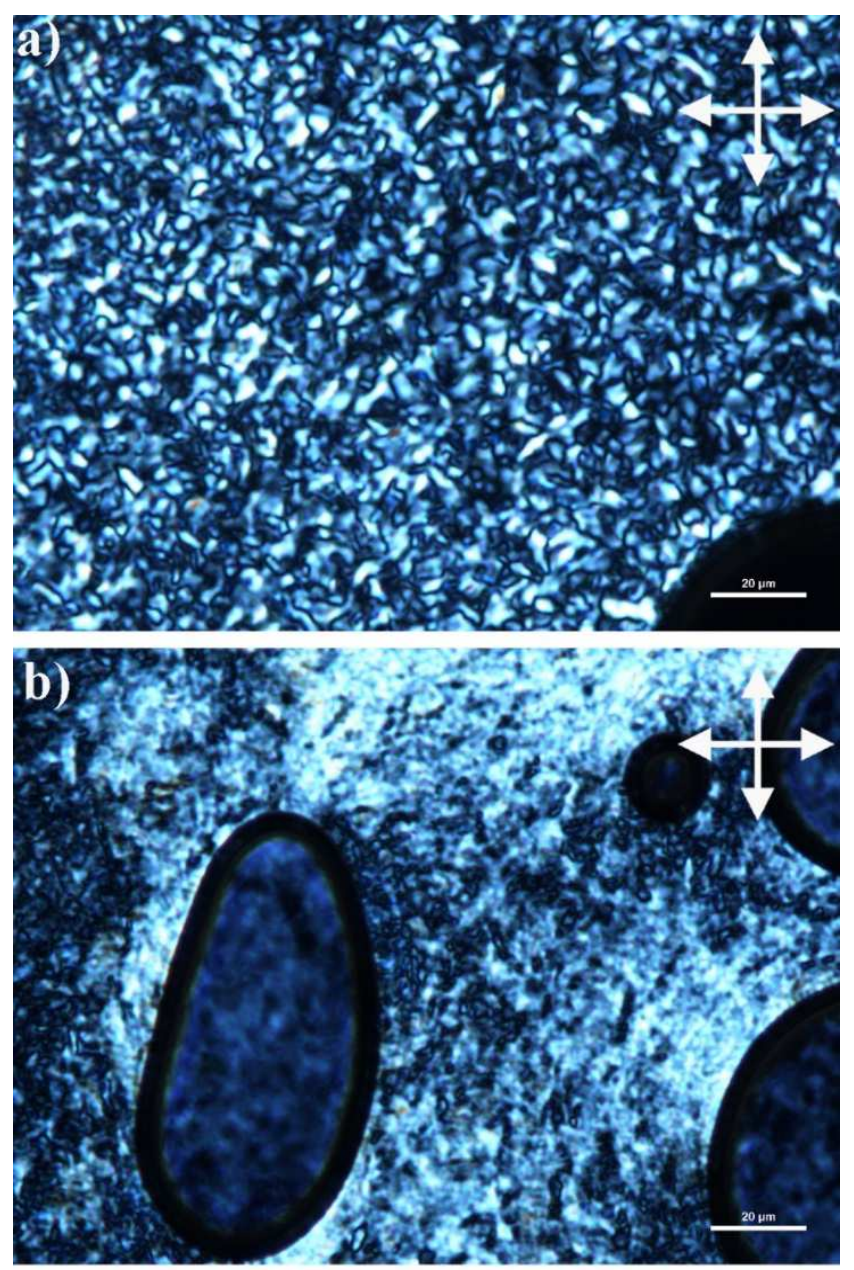

c)

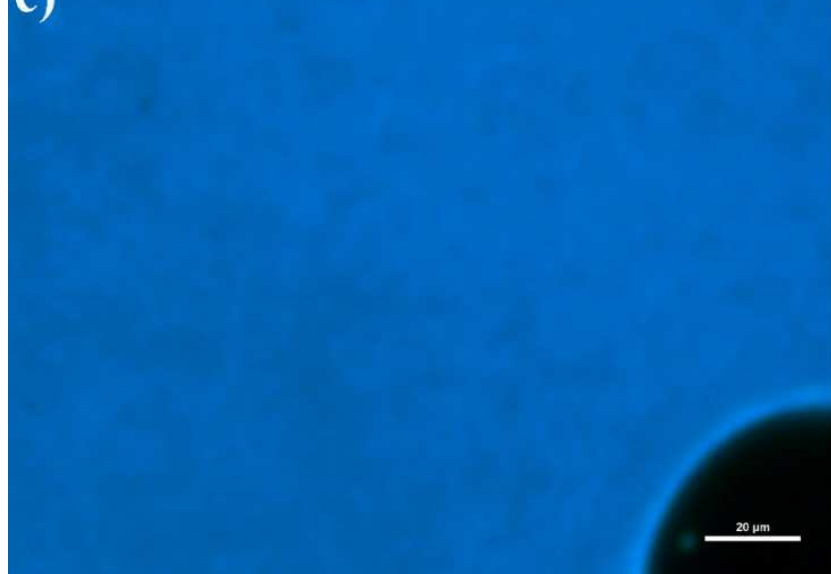

Figure S5. (a) Pseudo-fan shaped Textures observed with BPM-(R)-C8(2) compound at 91 ${ }^{\circ} \mathrm{C}$ on slow cooling from the isotropic phase (rate $=0.1{ }^{\circ} \mathrm{C} / \mathrm{min}$ ); (b) same area after gentle pressure on the cover glass slide showing the fluidity of the birefringent phase; (c) area of (a) observed upon irradiation at $340<\lambda_{\mathrm{ex}}<380 \mathrm{~nm}$. 

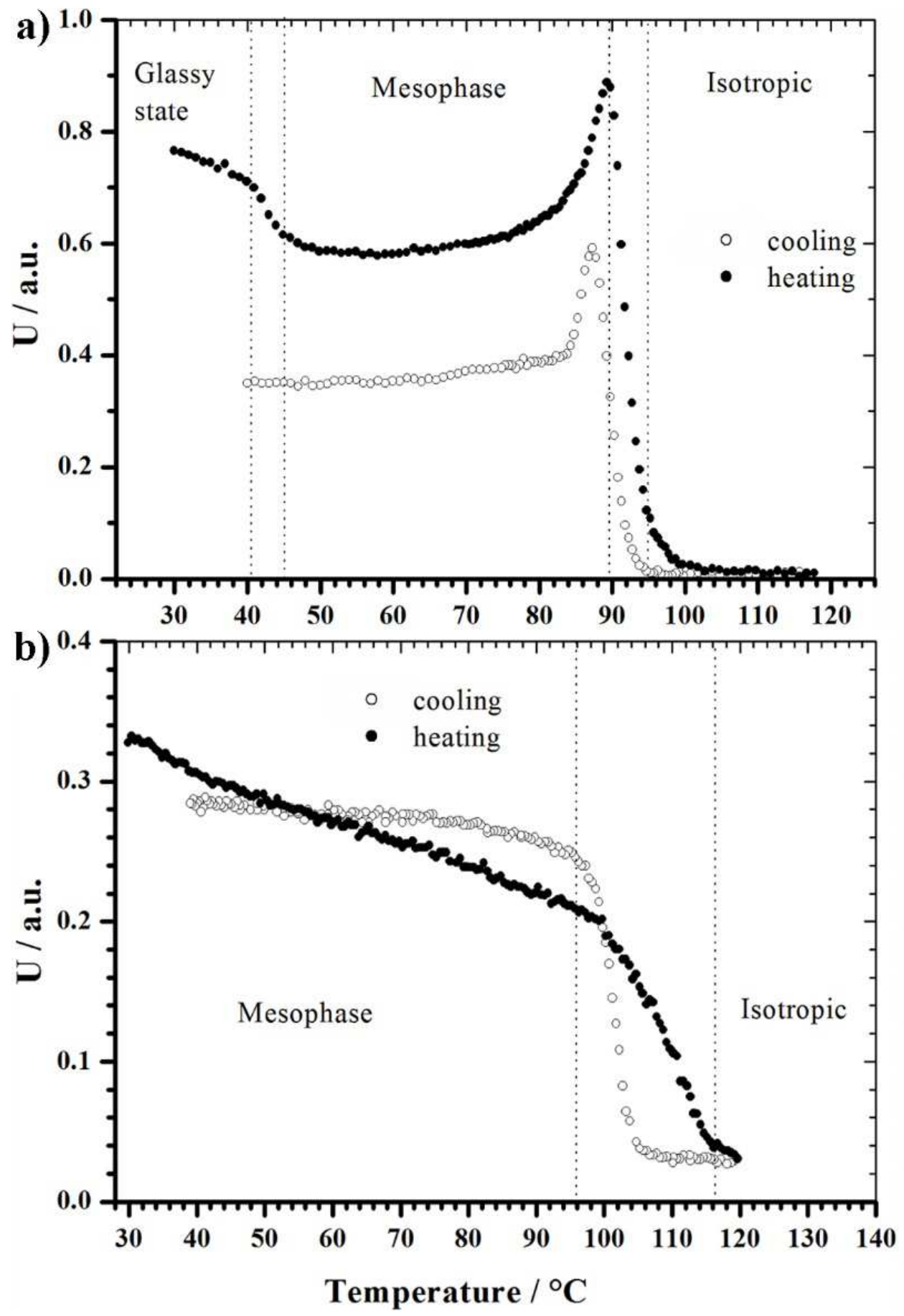

Figure S6. Intensity of the transmitted light in the polarizing microscope as a function of the temperature for BPM-(R)-C8(2) (a) and BPM-(S)-C8(2) (b) compounds. Dotted lines indicate the mesophase domains upon heating and cooling respectively (scan rate $=1.8$ $\left.{ }^{\circ} \mathrm{C} / \mathrm{min}\right)$. 

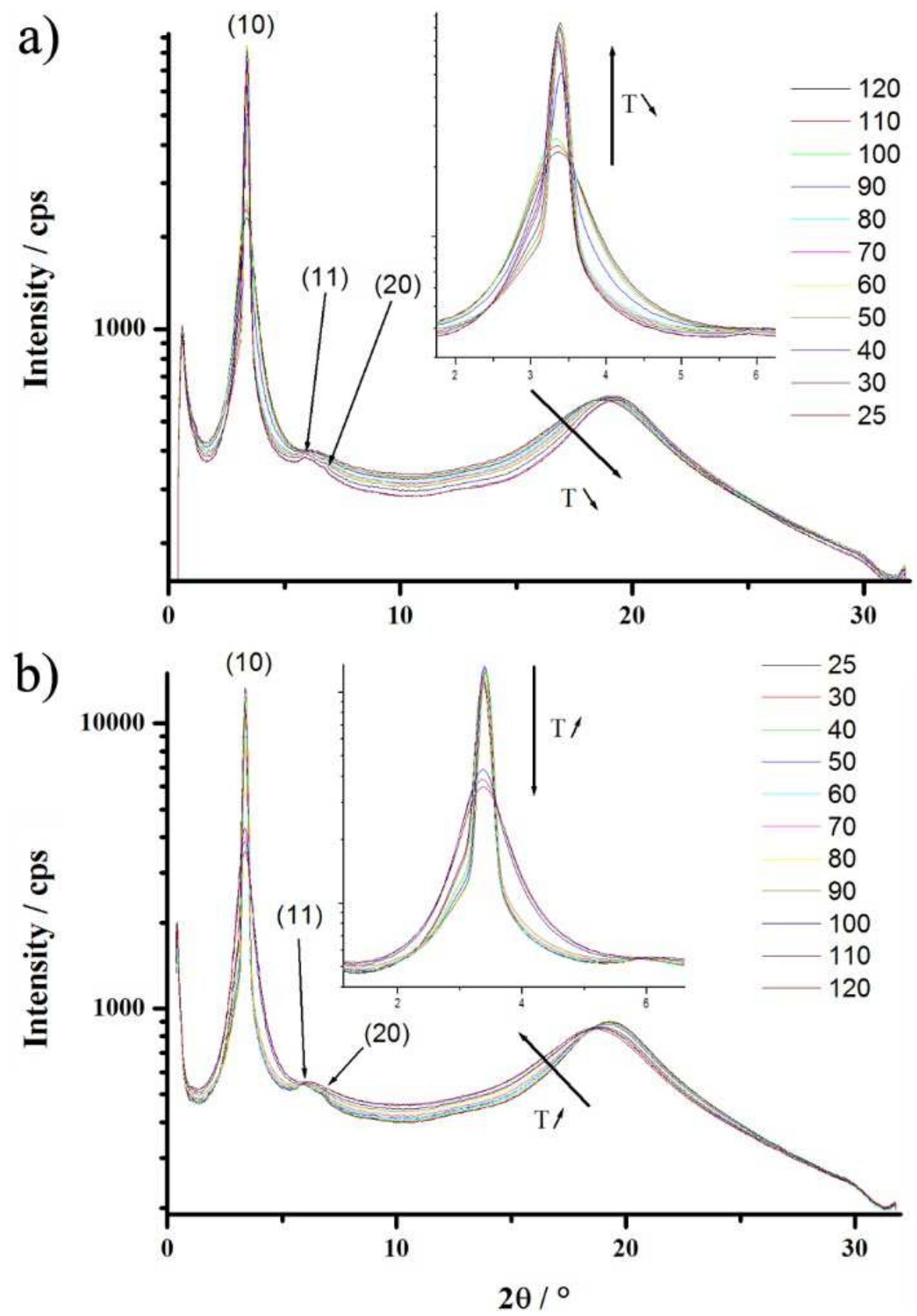

Figure S7. a) Temperature-dependent SAXS patterns of BPM-(R)-C8(2) upon cooling from the isotropic phase; b) Temperature-dependent SAXS patterns of BPM-(S)-C8(2) upon heating (measurements performed after a first heating and cooling cycle up to the isotropic phase). 

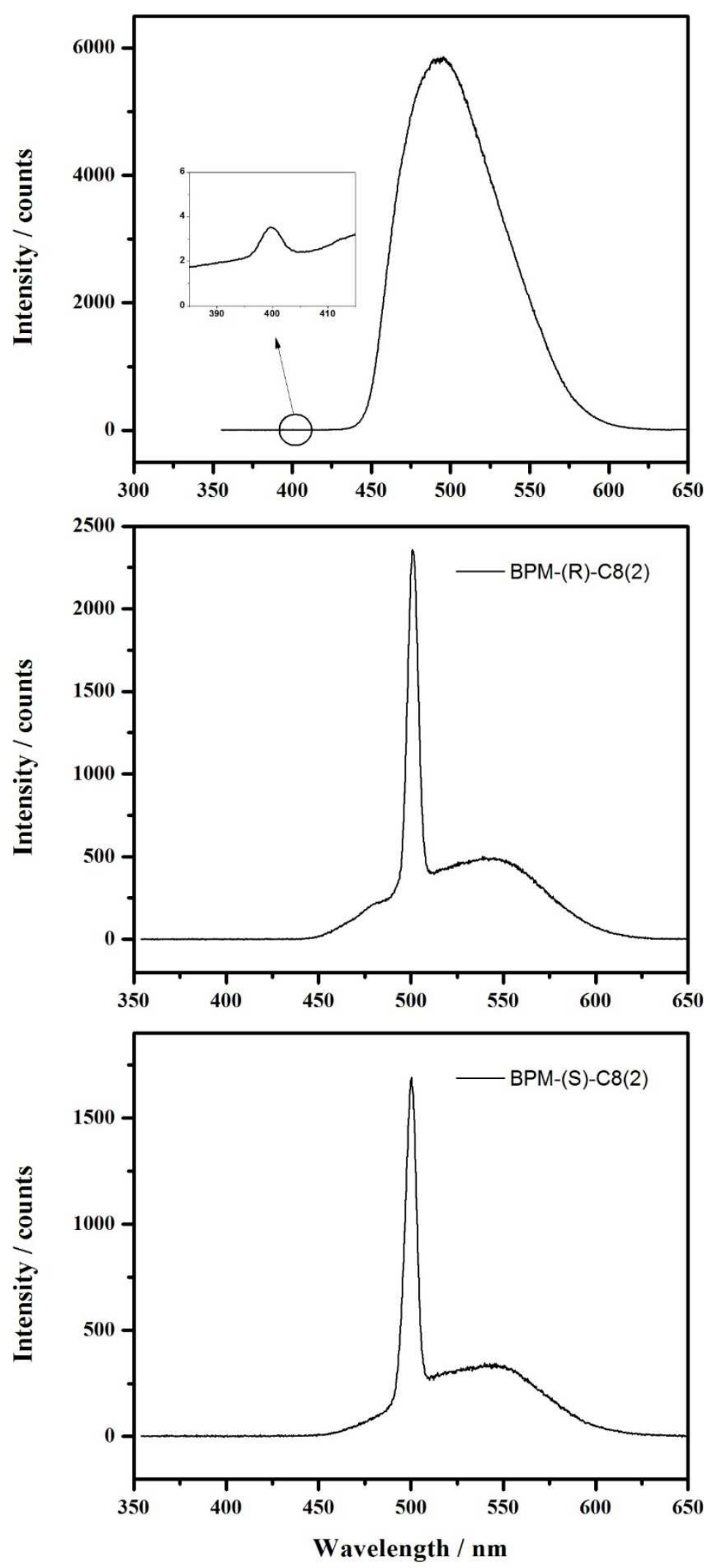

Figure S8. (above) Solid state multiphoton emission spectrum of BPM-(S)-C8(2) compound at room temperature, excitation wavelength $800 \mathrm{~nm}, \mathrm{P}_{\mathrm{in}}=5 \mathrm{~mW}$. The inset shows the SHG peak which is dominated by multiphoton fluorescence.(middle and below) ) Solid state multiphoton emission spectrum of BPM-(S)-C8(2) and BPM-(R)-C8(2) compound at room temperature, excitation wavelength $1000 \mathrm{~nm}, \mathrm{P}_{\mathrm{in}}=75 \mathrm{~mW}$. 
To relate the average effective nonlinear optical coefficient at room temperature to its value at different temperatures the following formula was used:

$\mathrm{I}^{2 \omega}=\mathrm{A} \frac{\left\langle\mathrm{d}_{\text {eff }}\right\rangle^{2}}{\mathrm{n}_{2 \omega} \mathrm{n}_{\omega}^{2}} \mathrm{r}^{2}\left(\mathrm{I}^{\omega}\right)^{2}$

In which $\mathrm{A}$ is a proportionality factor, $I_{\omega}$ is the intensity of the incident laser light, $\mathrm{n}_{\omega}$ and $\mathrm{n}_{2_{\omega}}$ are the refractive indexes at the first and second-harmonic wavelengths, $r$ is the thickness of the film and $<$ deff $>$ is the effective nonlinear coefficient averaged over different polarization orientations of the excitation light (see experimental section). An estimate for the refractive index was based on the work of $\mathrm{Li}$ et al., in which the refractive index of 7 commercial liquid crystals was measured. ${ }^{[9]}$ The average $\mathrm{n}_{400 \mathrm{~nm}}$ from these measurements is $1.58 \pm 0.03$, and $\mathrm{n}_{800 \mathrm{~nm}} 1.53 \pm 0.02$. We used these values as an estimate to calculate $\left\langle\mathrm{d}_{\mathrm{eff}}\right\rangle$. For simplicity, we assume all constants remain identical for different temperatures, with $<\mathrm{d}_{\mathrm{eff}}>$ proportional to the square root of the SHG intensity.

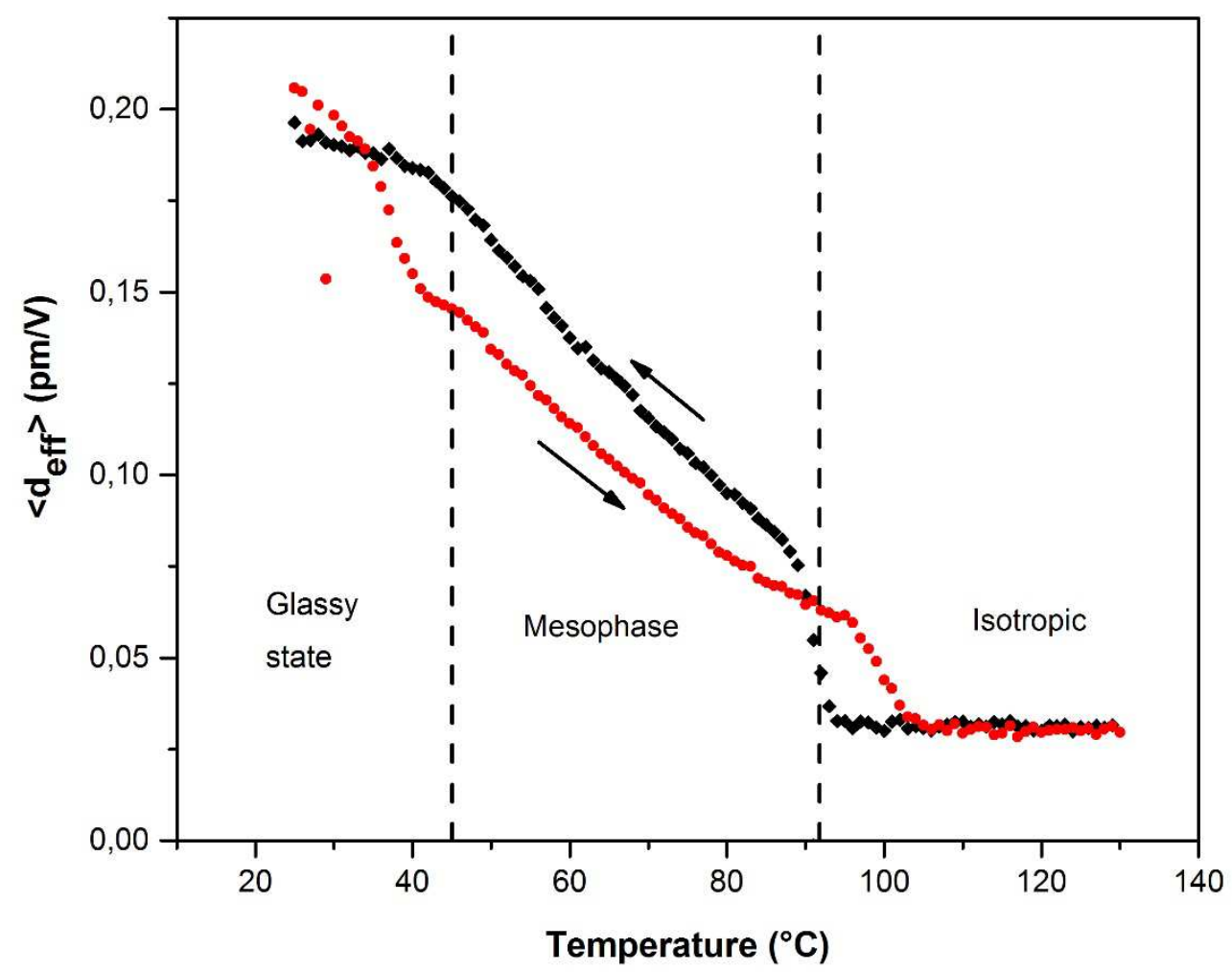

Figure S9. Average nonlinear optical coefficient $\left\langle\mathrm{d}_{\mathrm{eff}}\right\rangle$ at different temperatures. 


\section{Geometry Optimization of BPM-(S)-C8(2) compound}

\# opt rb3lyp/6-31g(d) geom=connectivity

\section{Cartesians Coordinates for the Optimized Geometry}

$\begin{array}{lccc}\mathrm{C} & -0.78304974 & 2.42915055 & -1.56437950 \\ \mathrm{C} & -1.42212260 & 3.22568168 & -0.60678300 \\ \mathrm{C} & -4.22636310 & 6.29503599 & 15.34530216 \\ \mathrm{C} & -0.04129381 & 2.94919877 & -2.71643445 \\ \mathrm{C} & -2.10052360 & 2.58639475 & 0.43905868 \\ \mathrm{C} & -1.49208781 & 0.56302247 & -0.44381716 \\ \mathrm{C} & -1.53222856 & -0.93897599 & -0.35561142 \\ \mathrm{C} & -4.36490516 & 16.60490346 & -1.16976493 \\ \mathrm{C} & -2.81165316 & 3.28201354 & 1.51404955 \\ \mathrm{C} & -4.38850535 & 18.29795124 & 0.70205545 \\ \mathrm{C} & -2.66249571 & -2.82717501 & 0.27871501 \\ \mathrm{C} & 5.97996930 & 15.96169856 & -7.36644370 \\ \mathrm{C} & -0.50938016 & -2.94443006 & -0.77735970 \\ \mathrm{C} & -1.60508730 & -3.60548597 & -0.20851550 \\ \mathrm{C} & -3.87878593 & -3.36782917 & 0.89337700 \\ \mathrm{C} & 0.66835159 & -3.61418895 & -1.33676711 \\ \mathrm{C} & -2.93017044 & 4.61799335 & 1.66307085 \\ \mathrm{C} & -3.63915168 & 5.33127975 & 2.72403489 \\ \mathrm{C} & -3.66193639 & 6.74376258 & 2.68766710 \\ \mathrm{C} & -4.30033573 & 4.69330711 & 3.78076758 \\ \mathrm{C} & -4.31827103 & 7.49235709 & 3.65777490 \\ \mathrm{C} & -4.98738049 & 6.82748106 & 4.71867187 \\ \mathrm{C} & -4.96130474 & 5.43128033 & 4.76219805 \\ \mathrm{C} & -4.15387839 & -4.66735143 & 1.12516940 \\ \mathrm{C} & -5.36791363 & -5.21511132 & 1.73394084 \\ \mathrm{C} & -6.46328027 & -4.42562104 & 2.11882615 \\ \mathrm{C} & -5.44098714 & -6.60804819 & 1.94388499 \\ \mathrm{C} & -7.59016989 & -5.01655826 & 2.68163749 \\ \mathrm{C} & -7.66245735 & -6.39404463 & 2.88662259 \\ \mathrm{C} & -6.56298039 & -7.20359120 & 2.52038111 \\ \mathrm{C} & 0.12480018 & 4.24653984 & -3.04570431 \\ \mathrm{C} & 0.86187055 & 4.77979640 & -4.19112530 \\ \mathrm{C} & 1.52330351 & 3.97806121 & -5.13543360 \\ \mathrm{C} & 0.92630877 & 6.17576891 & -4.36905806 \\ \mathrm{C} & 2.20426046 & 4.54209048 & -6.21107360 \\ \mathrm{C} & 2.24804253 & 5.93219163 & -6.38292349 \\ \mathrm{C} & 1.60115296 & 6.75681997 & -5.43443010 \\ \mathrm{C} & 0.85248926 & -4.94339813 & -1.47032952 \\ \mathrm{C} & 2.02137613 & -5.61377208 & -2.04276234 \\ \mathrm{C} & 1.98193569 & -7.01436085 & -2.20106816\end{array}$




\begin{tabular}{|c|c|c|c|}
\hline $\mathrm{C}$ & 3.17879298 & -4.93227034 & -2.45255073 \\
\hline $\mathrm{C}$ & 3.04793435 & -7.72114740 & -2.75914501 \\
\hline $\mathrm{C}$ & 4.21113605 & -7.01974772 & -3.15100433 \\
\hline $\mathrm{C}$ & 4.25137986 & -5.63347208 & -2.99140890 \\
\hline $\mathrm{C}$ & 4.36789913 & 17.59745884 & -6.31868656 \\
\hline $\mathrm{C}$ & 5.42017439 & 6.23851710 & -16.21603528 \\
\hline $\mathrm{C}$ & 6.65535203 & 8.43435604 & -16.37317642 \\
\hline $\mathrm{C}$ & 11.87930638 & -13.90153173 & $\begin{array}{ll}3 & -4.77501447\end{array}$ \\
\hline $\mathrm{C}$ & 13.83171256 & -12.36882762 & $2 \quad-5.23228942$ \\
\hline $\mathrm{C}$ & -1.90118504 & -16.47556883 & -5.07640458 \\
\hline $\mathrm{C}$ & -0.09104713 & -18.23254557 & -4.98794018 \\
\hline $\mathrm{C}$ & -3.33740529 & -17.29969403 & 2.96258285 \\
\hline $\mathrm{C}$ & -9.61566445 & -7.75863945 & 2.69957230 \\
\hline $\mathrm{C}$ & -10.77541380 & -8.20402995 & 3.58108789 \\
\hline $\mathrm{C}$ & -11.86963900 & -9.00245237 & 2.84292637 \\
\hline $\mathrm{C}$ & -11.33654484 & -10.33919723 & $\begin{array}{ll}3 & 2.30011904\end{array}$ \\
\hline $\mathrm{C}$ & -13.08653098 & -9.19723764 & 3.77225744 \\
\hline $\mathrm{C}$ & -14.33232303 & -9.80475371 & 3.11110267 \\
\hline $\mathrm{C}$ & -15.54206212 & -9.84284082 & 4.05656823 \\
\hline $\mathrm{C}$ & -16.85029671 & -10.37228467 & $7 \quad 3.43563173$ \\
\hline $\mathrm{C}$ & -5.57924909 & -9.39916570 & 2.51585352 \\
\hline $\mathrm{C}$ & -5.98601642 & -10.80348745 & 2.94780440 \\
\hline $\mathrm{C}$ & -4.93637690 & -11.89459728 & 2.65213189 \\
\hline $\mathrm{C}$ & -3.63757606 & -11.67263684 & 3.44556618 \\
\hline $\mathrm{C}$ & -5.54953102 & -13.28560863 & 2.92179720 \\
\hline $\mathrm{C}$ & -4.69191141 & -14.48151878 & 2.48302274 \\
\hline $\mathrm{C}$ & -5.41162405 & -15.82451582 & 2.67579507 \\
\hline $\mathrm{C}$ & -4.63904411 & -17.06390953 & 2.18068909 \\
\hline $\mathrm{C}$ & 1.89189403 & -9.82750495 & -2.63368812 \\
\hline $\mathrm{C}$ & 2.16516553 & -11.27649216 & -3.02127593 \\
\hline $\mathrm{C}$ & 0.96328991 & -12.22529591 & -2.83531966 \\
\hline $\mathrm{C}$ & 0.56161177 & -12.36220428 & -1.35704281 \\
\hline $\mathrm{C}$ & 1.28116110 & -13.59230907 & -3.47721196 \\
\hline $\mathrm{C}$ & 0.10544498 & -14.57745460 & -3.55435931 \\
\hline $\mathrm{C}$ & 0.46651047 & -15.85874914 & -4.32020778 \\
\hline $\mathrm{C}$ & -0.62953945 & -16.94249939 & -4.35103788 \\
\hline $\mathrm{C}$ & 5.95468188 & -8.68775150 & -3.05196955 \\
\hline $\mathrm{C}$ & 7.35455938 & -8.78670659 & -3.64767744 \\
\hline $\mathrm{C}$ & 8.17854980 & -9.99800633 & -3.16716358 \\
\hline $\mathrm{C}$ & 8.41666220 & -9.96689558 & -1.64823513 \\
\hline $\mathrm{C}$ & 9.50154615 & -10.06470214 & -3.95944584 \\
\hline $\mathrm{C}$ & 10.33846707 & -11.33630247 & $\begin{array}{ll}7 & -3.75529920\end{array}$ \\
\hline $\mathrm{C}$ & 11.58765283 & -11.36091668 & $8 \quad-4.64843083$ \\
\hline $\mathrm{C}$ & 12.53608134 & -12.55652430 & ) -4.42844765 \\
\hline $\mathrm{C}$ & 3.52499001 & 5.78288681 & -8.41386285 \\
\hline $\mathrm{C}$ & 4.10384337 & 6.74812400 & -9.44163879 \\
\hline $\mathrm{C}$ & 4.75036901 & 6.06509847 & -10.66450672 \\
\hline $\mathrm{C}$ & 5.97999280 & 5.22846369 & -10.27259027 \\
\hline $\mathrm{C}$ & 5.08760604 & 7.12956285 & -11.73016730 \\
\hline $\mathrm{C}$ & 5.56272818 & 6.58160758 & -13.08390748 \\
\hline
\end{tabular}




\begin{tabular}{|c|c|c|c|}
\hline $\mathrm{C}$ & 5.75228338 & $7.68841826-$ & -14.13175273 \\
\hline $\mathrm{C}$ & 6.33977496 & $7.22504860-$ & -15.47983881 \\
\hline $\mathrm{C}$ & 2.80685379 & 8.81961988 & -5.38488678 \\
\hline $\mathrm{C}$ & 2.49412475 & 10.31078110 & -5.41309701 \\
\hline $\mathrm{C}$ & 3.73348896 & 11.22790776 & -5.38722945 \\
\hline $\mathrm{C}$ & 4.55756691 & 11.04524054 & -4.10140973 \\
\hline $\mathrm{C}$ & 3.29650731 & 12.69399053 & -5.59087310 \\
\hline $\mathrm{C}$ & 4.43678296 & 13.70243816 & -5.79397064 \\
\hline $\mathrm{C}$ & 3.92289979 & 15.11789634 & -6.09642809 \\
\hline $\mathrm{C}$ & 5.00938188 & 16.20661899 & -6.20070088 \\
\hline $\mathrm{C}$ & -3.71405263 & 9.58853977 & 2.66382334 \\
\hline $\mathrm{C}$ & -3.94947425 & 11.06871558 & 2.94336565 \\
\hline $\mathrm{C}$ & -3.37937348 & 12.01732809 & 1.86894302 \\
\hline $\mathrm{C}$ & -1.84408788 & 11.95194427 & 1.80055440 \\
\hline $\mathrm{C}$ & -3.88460210 & 13.45374973 & 2.12124309 \\
\hline $\mathrm{C}$ & -3.57481148 & 14.46449330 & 1.00717547 \\
\hline $\mathrm{C}$ & -4.20470780 & 15.84054862 & 1.26878411 \\
\hline $\mathrm{C}$ & -3.85223903 & 16.93433090 & 0.24082659 \\
\hline $\mathrm{C}$ & -6.32422609 & 7.07364294 & 6.71682571 \\
\hline $\mathrm{C}$ & -5.39479838 & 6.74214763 & 7.88715559 \\
\hline $\mathrm{C}$ & -6.12921565 & 6.30484137 & 9.17221248 \\
\hline $\mathrm{C}$ & -6.84628495 & 4.95617969 & 8.98936412 \\
\hline $\mathrm{C}$ & -5.13912825 & 6.27748048 & 10.35600453 \\
\hline $\mathrm{C}$ & -5.77118083 & 6.05933171 & 11.73864647 \\
\hline $\mathrm{C}$ & -4.74175215 & 6.13764131 & 12.87552420 \\
\hline $\mathrm{C}$ & -5.31950238 & 6.02303353 & 14.30058308 \\
\hline $\mathrm{C}$ & -18.02520032 & -10.16875892 & 24.40431480 \\
\hline $\mathrm{C}$ & -16.75094394 & -11.84707277 & $7 \quad 3.01606697$ \\
\hline $\mathrm{C}$ & -5.53243521 & -18.31219315 & 2.23911687 \\
\hline $\mathrm{C}$ & -5.98443312 & 4.66258158 & 14.56116917 \\
\hline $\mathrm{H}$ & -6.44388630 & -3.35097835 & 1.97162380 \\
\hline $\mathrm{H}$ & -3.41411452 & -5.41699647 & 0.84511573 \\
\hline $\mathrm{H}$ & -5.45434685 & 4.90353464 & 5.57007125 \\
\hline $\mathrm{H}$ & -4.30270056 & 3.61056135 & 3.85162323 \\
\hline $\mathrm{H}$ & -3.15347124 & 7.24853973 & 1.87371660 \\
\hline $\mathrm{H}$ & -2.45923180 & 5.26784292 & 0.92568021 \\
\hline $\mathrm{H}$ & 1.42353339 & -2.91212717 & -1.67924745 \\
\hline $\mathrm{H}$ & -4.58537680 & -2.59125752 & 1.17325266 \\
\hline $\mathrm{H}$ & -1.63359579 & -4.68738050 & -0.14767523 \\
\hline $\mathrm{H}$ & -3.26956292 & 2.59947316 & 2.22491387 \\
\hline $\mathrm{H}$ & 0.39089461 & 2.16003511 & -3.32585643 \\
\hline $\mathrm{H}$ & -4.59343478 & -7.21974433 & 1.65420225 \\
\hline $\mathrm{H}$ & -6.36996087 & 4.60535989 & 15.58608210 \\
\hline $\mathrm{H}$ & -5.26288834 & 3.84468365 & 14.43241659 \\
\hline $\mathrm{H}$ & -6.82410782 & 4.47678520 & 13.88302815 \\
\hline $\mathrm{H}$ & -4.63114272 & 6.25948210 & 16.36377961 \\
\hline $\mathrm{H}$ & -3.76919943 & 7.28111551 & 15.19949171 \\
\hline $\mathrm{H}$ & -3.42727706 & 5.54490982 & 15.27967847 \\
\hline $\mathrm{H}$ & -4.11445943 & 17.40662440 & -1.87469662 \\
\hline $\mathrm{H}$ & -5.45737846 & 16.49227067 & -1.17056092 \\
\hline
\end{tabular}




\begin{tabular}{|c|c|c|c|}
\hline $\mathrm{H}$ & -3.93385483 & 15.67693051 & -1.56043488 \\
\hline $\mathrm{H}$ & -4.10663084 & 19.09404068 & 0.00265204 \\
\hline $\mathrm{H}$ & -4.00009505 & 18.56664565 & 1.69175585 \\
\hline $\mathrm{H}$ & -5.48455488 & 18.28639221 & 0.76668159 \\
\hline $\mathrm{H}$ & 6.73184206 & 16.75780880 & -7.42398781 \\
\hline $\mathrm{H}$ & 5.44242878 & 15.94373506 & -8.32406698 \\
\hline $\mathrm{H}$ & 6.51404509 & 15.01079573 & -7.26575762 \\
\hline $\mathrm{H}$ & 5.12935645 & 18.38598152 & -6.34883590 \\
\hline $\mathrm{H}$ & 3.70284787 & 17.80480546 & -5.47173726 \\
\hline $\mathrm{H}$ & 3.77155618 & 17.67748076 & -7.23717564 \\
\hline $\mathrm{H}$ & 5.85774227 & 5.93682537 & -17.17510560 \\
\hline $\mathrm{H}$ & 4.44518789 & 6.69803499 & -16.42692765 \\
\hline $\mathrm{H}$ & 5.24117452 & 5.32756969 & -15.63488076 \\
\hline $\mathrm{H}$ & 7.11411669 & 8.12162371 & -17.31875462 \\
\hline $\mathrm{H}$ & 7.34523417 & 9.12850509 & -15.87837162 \\
\hline $\mathrm{H}$ & 5.74102360 & 8.99122820 & -16.61687376 \\
\hline $\mathrm{H}$ & 12.57926300 & -14.73124166 & $5-4.61969501$ \\
\hline $\mathrm{H}$ & 11.56866685 & -13.92297691 & -5.82823413 \\
\hline $\mathrm{H}$ & 10.99347986 & -14.09926866 & $5-4.16190681$ \\
\hline $\mathrm{H}$ & 14.53385992 & -13.19230637 & $7 \quad-5.05520432$ \\
\hline $\mathrm{H}$ & 14.33695714 & -11.43308333 & $3-4.96442688$ \\
\hline $\mathrm{H}$ & 13.62292891 & -12.33716901 & -6.30980495 \\
\hline $\mathrm{H}$ & -2.65413139 & -17.27239176 & -5.09797036 \\
\hline $\mathrm{H}$ & -1.67863669 & -16.20197896 & -6.11649126 \\
\hline $\mathrm{H}$ & -2.35800754 & -15.60507718 & -4.59331029 \\
\hline $\mathrm{H}$ & -0.84655735 & -19.02711156 & -4.97735861 \\
\hline $\mathrm{H}$ & 0.79352406 & -18.60254329 & -4.45579176 \\
\hline $\mathrm{H}$ & 0.19668840 & -18.06263072 & -6.03380478 \\
\hline $\mathrm{H}$ & -2.81955954 & -18.19509151 & 2.59872670 \\
\hline $\mathrm{H}$ & -3.54634735 & -17.44891180 & 4.03035665 \\
\hline $\mathrm{H}$ & -2.64133204 & -16.45869438 & 2.87328687 \\
\hline $\mathrm{H}$ & -5.00934270 & -19.19462383 & 1.85182982 \\
\hline $\mathrm{H}$ & -6.44701670 & -18.17785918 & 1.64928544 \\
\hline $\mathrm{H}$ & -5.83193361 & -18.53160321 & 3.27240519 \\
\hline $\mathrm{H}$ & -17.69686838 & -12.19608559 & $9 \quad 2.58490563$ \\
\hline $\mathrm{H}$ & -16.52687034 & -12.48409047 & $\begin{array}{ll}7 & 3.88225875\end{array}$ \\
\hline $\mathrm{H}$ & -15.96793391 & -12.01285204 & $4 \quad 2.26841666$ \\
\hline $\mathrm{H}$ & -18.97044160 & -10.50307400 & $\begin{array}{l}0 \\
0\end{array}$ \\
\hline $\mathrm{H}$ & -18.13825968 & -9.11342470 & 4.68006459 \\
\hline $\mathrm{H}$ & -17.87341213 & -10.73986817 & 5.32977620 \\
\hline $\mathrm{H}$ & -6.09033181 & 6.80196329 & 14.41094374 \\
\hline $\mathrm{H}$ & -4.20264365 & 7.09304189 & 12.79480223 \\
\hline $\mathrm{H}$ & -3.98396887 & 5.35117036 & 12.73443655 \\
\hline $\mathrm{H}$ & -6.27755874 & 5.08719991 & 11.76729872 \\
\hline $\mathrm{H}$ & -6.55117333 & 6.81851442 & 11.90307279 \\
\hline $\mathrm{H}$ & -4.58971425 & 7.22983522 & 10.37083922 \\
\hline $\mathrm{H}$ & -4.38461512 & 5.49690578 & 10.17307198 \\
\hline $\mathrm{H}$ & -7.39261284 & 4.66310374 & 9.89146528 \\
\hline $\mathrm{H}$ & -6.12361611 & 4.16031756 & 8.76469816 \\
\hline $\mathrm{H}$ & -7.57409444 & 4.98580185 & 8.17098293 \\
\hline
\end{tabular}




$\begin{array}{lccc}\mathrm{H} & -6.89201640 & 7.06805610 & 9.39786753 \\ \mathrm{H} & -4.80316341 & 7.64330209 & 8.09280821 \\ \mathrm{H} & -4.68052929 & 5.96342860 & 7.58845451 \\ \mathrm{H} & -6.91083135 & 6.20907347 & 6.38471285 \\ \mathrm{H} & -7.03053812 & 7.85605156 & 7.01312819 \\ \mathrm{H} & -2.75410200 & 17.00466755 & 0.19303676 \\ \mathrm{H} & -3.89059871 & 16.18549397 & 2.26504058 \\ \mathrm{H} & -5.29978725 & 15.73629065 & 1.31724819 \\ \mathrm{H} & -3.93701057 & 14.06132956 & 0.05146081 \\ \mathrm{H} & -2.48856727 & 14.58709562 & 0.89725771 \\ \mathrm{H} & -3.46704793 & 13.81863395 & 3.07224303 \\ \mathrm{H} & -4.97420512 & 13.41768698 & 2.26449274 \\ \mathrm{H} & -1.44624912 & 12.61427871 & 1.02508067 \\ \mathrm{H} & -1.48577383 & 10.94174876 & 1.57418133 \\ \mathrm{H} & -1.40032684 & 12.25467414 & 2.75834354 \\ \mathrm{H} & -3.77746439 & 11.69548603 & 0.89275176 \\ \mathrm{H} & -3.52345384 & 11.31527329 & 3.92526770 \\ \mathrm{H} & -5.03309190 & 11.21984760 & 3.02674333 \\ \mathrm{H} & -4.11604750 & 9.31459609 & 1.67620701 \\ \mathrm{H} & -2.64463836 & 9.33735272 & 2.67310496 \\ \mathrm{H} & 5.59250858 & 16.18483785 & -5.26645625 \\ \mathrm{H} & 3.21481520 & 15.40855318 & -5.30637307 \\ \mathrm{H} & 3.34153688 & 15.10285596 & -7.03146968 \\ \mathrm{H} & 5.08013841 & 13.35286171 & -6.61331493 \\ \mathrm{H} & 5.07254283 & 13.74075403 & -4.89886623 \\ \mathrm{H} & 2.68355022 & 13.00622617 & -4.73126261 \\ \mathrm{H} & 2.63221903 & 12.73887090 & -6.46615810 \\ \mathrm{H} & 5.44209920 & 11.69040053 & -4.09191462 \\ \mathrm{H} & 4.91031744 & 10.01466234 & -3.98601612 \\ \mathrm{H} & 3.95576863 & 11.29146592 & -3.21630947 \\ \mathrm{H} & 4.37203590 & 10.95107043 & -6.24171915 \\ \mathrm{H} & 1.83385293 & 10.55288419 & -4.56873722 \\ \mathrm{H} & 1.91733561 & 10.50712390 & -6.32609006 \\ \mathrm{H} & 3.50989625 & 8.55194906 & -6.18252719 \\ \mathrm{H} & 3.24195192 & 8.51248948 & -4.42445366 \\ \mathrm{H} & 7.28896665 & 6.70784065 & -15.26815368 \\ \mathrm{H} & 6.41475932 & 8.45892695 & -13.71050071 \\ \mathrm{H} & 4.78769182 & 8.18677014 & -14.31473577 \\ \mathrm{H} & 4.83376895 & 5.84312126 & -13.44472778 \\ \mathrm{H} & 6.51259107 & 6.04356429 & -12.96233414 \\ \mathrm{H} & 5.85037591 & 7.81257335 & -11.32553732 \\ \mathrm{H} & & & \end{array}$




\begin{tabular}{|c|c|c|c|}
\hline $\mathrm{H}$ & 12.80431525 & -12.57688334 & -3.36035004 \\
\hline $\mathrm{H}$ & 12.15368193 & -10.43279376 & -4.48075699 \\
\hline $\mathrm{H}$ & 11.28018312 & -11.33946209 & -5.70557619 \\
\hline $\mathrm{H}$ & 9.71065213 & -12.21421621 & -3.96078766 \\
\hline $\mathrm{H}$ & 10.65183557 & -11.42043377 & -2.70568604 \\
\hline $\mathrm{H}$ & 10.11198561 & -9.18399879 & -3.70686501 \\
\hline $\mathrm{H}$ & 9.26891216 & -9.97182174 & -5.03027905 \\
\hline $\mathrm{H}$ & 8.99982474 & -10.83084454 & -1.31311867 \\
\hline $\mathrm{H}$ & 7.47532266 & -9.97691423 & -1.08804446 \\
\hline $\mathrm{H}$ & 8.96601370 & -9.06097186 & -1.35918889 \\
\hline $\mathrm{H}$ & 7.60376668 & -10.90848442 & -3.40204686 \\
\hline $\mathrm{H}$ & 7.89935006 & -7.85676404 & -3.43348339 \\
\hline $\mathrm{H}$ & 7.24252282 & -8.83673543 & -4.73855498 \\
\hline $\mathrm{H}$ & 5.40236260 & -9.62484403 & -3.17897621 \\
\hline $\mathrm{H}$ & 5.98258603 & -8.44947421 & -1.98140250 \\
\hline $\mathrm{H}$ & -0.90053584 & -17.17132727 & -3.30821235 \\
\hline $\mathrm{H}$ & 1.37123454 & -16.29263490 & -3.86932924 \\
\hline $\mathrm{H}$ & 0.74022435 & -15.59870472 & -5.35448984 \\
\hline $\mathrm{H}$ & -0.74633925 & -14.07870319 & -4.03686453 \\
\hline $\mathrm{H}$ & -0.22886608 & -14.85001507 & -2.54396711 \\
\hline $\mathrm{H}$ & 2.11323000 & -14.06019072 & -2.92887025 \\
\hline $\mathrm{H}$ & 1.65329162 & -13.41666329 & -4.49691599 \\
\hline $\mathrm{H}$ & -0.30674920 & -13.01749066 & -1.23478385 \\
\hline $\mathrm{H}$ & 0.30024446 & -11.39603135 & -0.91148778 \\
\hline $\mathrm{H}$ & 1.38586902 & -12.78716626 & -0.76892629 \\
\hline $\mathrm{H}$ & 0.10890225 & -11.79463813 & -3.38228175 \\
\hline $\mathrm{H}$ & 3.02206288 & -11.64377790 & -2.43989380 \\
\hline $\mathrm{H}$ & 2.47467832 & -11.28268994 & -4.07402503 \\
\hline $\mathrm{H}$ & 1.01917999 & -9.43941784 & -3.17982450 \\
\hline $\mathrm{H}$ & 1.69142264 & -9.72398539 & -1.55875556 \\
\hline $\mathrm{H}$ & -4.37308907 & -16.89055535 & 1.12598359 \\
\hline $\mathrm{H}$ & -6.37706793 & -15.78316469 & 2.15037317 \\
\hline $\mathrm{H}$ & -5.65380037 & -15.95800803 & 3.74165218 \\
\hline $\mathrm{H}$ & -3.74770655 & -14.48705689 & 3.04032233 \\
\hline $\mathrm{H}$ & -4.42331059 & -14.36466047 & 1.42189436 \\
\hline $\mathrm{H}$ & -6.51800720 & -13.34314517 & 2.40432393 \\
\hline $\mathrm{H}$ & -5.77528545 & -13.37410537 & 3.99554353 \\
\hline $\mathrm{H}$ & -2.89007619 & -12.43894779 & 3.21746086 \\
\hline $\mathrm{H}$ & -3.83212051 & -11.70644577 & 4.52562944 \\
\hline $\mathrm{H}$ & -3.18111289 & -10.70233347 & 3.22157952 \\
\hline $\mathrm{H}$ & -4.69255010 & -11.84467766 & 1.57835686 \\
\hline $\mathrm{H}$ & -6.92199926 & -11.05124374 & 2.43095866 \\
\hline $\mathrm{H}$ & -6.21652931 & -10.78790000 & 4.02152838 \\
\hline $\mathrm{H}$ & -4.70460871 & -9.03898105 & 3.07298523 \\
\hline $\mathrm{H}$ & -5.32984515 & -9.38079727 & 1.44397180 \\
\hline $\mathrm{H}$ & -17.05466157 & -9.77723877 & 2.53155339 \\
\hline $\mathrm{H}$ & -15.72283430 & -8.82564134 & 4.43391508 \\
\hline $\mathrm{H}$ & -15.29523676 & -10.45230992 & 4.94006109 \\
\hline $\mathrm{H}$ & -14.10945415 & -10.81843930 & 2.75705849 \\
\hline $\mathrm{H}$ & -14.59125914 & -9.21645826 & 2.21742474 \\
\hline
\end{tabular}




$\begin{array}{lrrr}\mathrm{H} & -13.35842802 & -8.21891491 & 4.19420507 \\ \mathrm{H} & -12.78699147 & -9.82176443 & 4.62804400 \\ \mathrm{H} & -12.10965851 & -10.89203082 & 1.75675911 \\ \mathrm{H} & -10.98333818 & -10.97749342 & 3.12109468 \\ \mathrm{H} & -10.49883614 & -10.19322929 & 1.60967081 \\ \mathrm{H} & -12.20469700 & -8.39724526 & 1.98491853 \\ \mathrm{H} & -11.21849555 & -7.30331904 & 4.02524844 \\ \mathrm{H} & -10.37693005 & -8.79942489 & 4.41398478 \\ \mathrm{H} & -9.03577175 & -8.60711256 & 2.32581854 \\ \mathrm{H} & -9.98220542 & -7.18121801 & 1.83722768 \\ \mathrm{H} & 5.15359428 & -5.11919500 & -3.30813770 \\ \mathrm{H} & 3.25083642 & -3.85570417 & -2.33961232 \\ \mathrm{H} & 1.08526239 & -7.54342253 & -1.89702337 \\ \mathrm{H} & 0.06206434 & -5.61771488 & -1.14133783 \\ \mathrm{H} & 2.69457993 & 3.88940718 & -6.92414481 \\ \mathrm{H} & 0.43052590 & 6.84236682 & -3.66843180 \\ \mathrm{H} & 1.50780520 & 2.89706585 & -5.03974397 \\ \mathrm{H} & -0.32700899 & 5.00968648 & -2.41275325 \\ \mathrm{H} & -8.44351996 & -4.41692331 & 2.98390458 \\ \mathrm{H} & -1.39234628 & 4.30706974 & -0.67221934 \\ \mathrm{~N} & -2.13601270 & 1.23735210 & 0.51345300 \\ \mathrm{~N} & -2.62015475 & -1.47943229 & 0.20240133 \\ \mathrm{~N} & -0.47721299 & -1.59621154 & -0.84748396 \\ \mathrm{~N} & -0.81675716 & 1.08141922 & -1.47407345 \\ \mathrm{O} & -8.76981203 & -6.91519039 & 3.50400166 \\ \mathrm{O} & 5.28031546 & -7.62439057 & -3.75269860 \\ \mathrm{O} & 3.05190996 & -9.07034073 & -2.97891190 \\ \mathrm{O} & -6.69043331 & -8.53998479 & 2.77286781 \\ \mathrm{O} & -4.38590333 & 8.85326381 & 3.68431391 \\ \mathrm{O} & 2.86637334 & 6.56834963 & -7.41696420 \\ \mathrm{O} & -5.61784463 & 7.64004792 & 5.60890011 \\ \mathrm{O} & 1.56230454 & 8.12242050 & -5.57557702 \\ & & & \\ & & & \\ & & & \end{array}$

\section{References}

[1]. Gaussian 09, Revision A.02, M. J. Frisch, G. W. Trucks, H. B. Schlegel, G. E. Scuseria, M. A. Robb, J. R. Cheeseman, G. Scalmani, V. Barone, G. A. Petersson, H. Nakatsuji, X. Li, M. Caricato, A. Marenich, J. Bloino, B. G. Janesko, R. Gomperts, B. Mennucci, H. P. Hratchian, J. V. Ortiz, A. F. Izmaylov, J. L. Sonnenberg, D. Williams-Young, F. Ding, F. Lipparini, F. Egidi, J. Goings, B. Peng, A. Petrone, T. Henderson, D. Ranasinghe, V. G. Zakrzewski, J. Gao, N. Rega, G. Zheng, W. Liang, M. Hada, M. Ehara, K. Toyota, R. Fukuda, J. Hasegawa, M. Ishida, T. Nakajima, Y. Honda, O. Kitao, H. Nakai, T. Vreven, K. Throssell, J. A. Montgomery, Jr., J. E. Peralta, F. Ogliaro, M. Bearpark, J. J. Heyd, E. Brothers, K. N. Kudin, V. N. Staroverov, T. Keith, R. Kobayashi, J. Normand, K. Raghavachari, A. Rendell, J. C. Burant, S. S. Iyengar, J. Tomasi, M. Cossi, J. M. Millam, M. Klene, C. Adamo, R. Cammi, J. W. Ochterski, R. L. Martin, K. Morokuma, O. Farkas, J. B. Foresman, and D. J. Fox, Gaussian, Inc., Wallingford CT, 2016. 
[2]. GaussView, Version 5, R. Dennington, T. Keith, J. Millam, Semichem Inc., Shawnee Mission, KS, 2009.

[3]. R. Meech, D. Phillips, J. Photochem. 1983, 23, 193-217.

[4]. S. Van Cleuvenbergen, I. Stassen, E. Gobechiya, Y. Zhang, K. Markey, E. Dirk, D. Vos, C. Kirschhock, B. Champagne, T. Verbiest, M.A. van der Veen, Chem. Mater. 2016, 28, 3203-3209.

[5]. S. Sankaranarayanan, A. Sharma, S. Chattopadhyay, Tetrahedron: Asymmetry 2002, $13,1373-1378$.

[6]. F. Camerel, B. Donnio, C. Bourgogne, M. Schmutz, D. Guillon, P. Davidson, R. Ziessel, Chem. Eur. J. 2006, 12, 4261-4274.

[7]. C.-Y. Liu, A. Fechtenkötter, M.D. Watson, K. Müllen, A.J. Bard, Chem. Mater. 2003, $15,124-130$.

[8]. A.S. Achalkumar, B.N. Veerabhadraswamy, U.S. Hiremath, D.S. Shankar Rao, S.K. Prasad, C.V. Yelamaggad, Dyes and Pigments 2016, 132, 291-305.

[9]. J. Li, G. Baird, Y.-H. Lin, H. Ren, S.-T. Wu, J. Soc. Inf. Disp. 2005, 13, 1017-1026. 